Buychik, A. (2021). The formation of klironomical thinking in the system of the social outlook. Eastern European bumanitarian collection of mini monographs. Collection of Scientific Works. European Scientific e-Journal, 1 (7), 103-148. Hlučín-Bobrovníky: “Anisiia Tomanek” OSVČ. (in Russian)

Буйчик, А.Г. (2021). Формирование клирономического мышления в системе общественного мировоззрения. Eastern European humanitarian collection of mini monographs. Collection of Scientific Works. European Scientific e-Journal, 1 (7), 103-148. Hlučín-Bobrovníky: "Anisiia Tomanek" OSVČ.

DOI: $10.47451 /$ phi2020-12-001

The paper will be published in Crossref, ICI Copernicus, Academic Resource Index ResearchBib, J-Gate, ISI International Scientific Indexing, Zenodo, OpenAIRE, BASE, LORY, LUASA, ADL, eLibrary, and WebArchive databases.

Alexander Buychik, Doctor of Economic Sciences, PhD of Social and Political Sciences, Director for Science, Tuculart Holding, Ostrava, Czech Republic. 0000-0002-2542-4198.

\title{
The formation of klironomical thinking in the system of the social outlook
}

Abstract: The preservation of the historical and cultural heritage of civilization is the most urgent and priority direction of the world community development as a whole and the society of each state individually. The cultural image of society cannot be formed from nowhere, from a blank slate. This is the result of centuries-old transformations, diffusions and interpenetration of semiotic series, traditions, folklore, in its essence the formation of intangible cultural heritage and transfer into a material shell, which begins to form the heritage value's concept, first in economic perception (equivalent), and then spiritual - the values of the past for future society. The expanded paper, based on the first two chapters of the monograph on klironomy, a new science on the cultural heritage preservation being developed, is an analysis of the evolution of the formation of a special kind of outlook in a person and society based on klironomical thinking, i.e., thoughts about preserving the past for the future. The author concludes that the individual and social outlook began to expand not only in philosophical terms, but also culturological and art criticism. Gradually, understanding not only the very essence of the preservation of cultural heritage, but also its processes and patterns, led to the formation of a separate direction of outlook, which requires a new name and definition - klironomical.

Keywords: outlook, klironomy, klironomical thinking, historical and cultural heritage, preservation of cultural heritage.

Александр Геннадьевич Буйчик, А-р экон. н., $\mathrm{PhD}$ соц. и полит. н., Аиректор по науке, Tuculart Holding. Острава, Чехия. ORCID: 0000-0002-2542-4198.

\section{Формирование клирономического мышиения в системе общественного мировоззрения}

Аннотачия: Сохранение историко-культурного наследия цивилизации является наиболее актуальным и приоритетным направлением развития мирового сообщества в целом и общества кажАого государства в отдельности. Культурный облик общества не может быть сформирован из ниоткуда, с чистого миста. Это - результат многовековых трансформаций, Аиффузий и взаимопроникновений семиотических рядов, традиций, фольклора, по своей сущности формирование нематериального культурного наследия и его переноса в материальную оболочку, что начинает формировать понятие ценности наследия, сначала в экономическом восприятии (эквиваленте), а затем и духовном - ценности прошлого Аля общества в будущем. Расширенная 
статья, основанная на первых двух главах монографии о клирономии - разрабатываемой новой науке о сохранении культурного наследия, представ яяет собой анализ эволюции формирования у человека и общества особого рода мировоззрения, основанного на клирономическом мышлении, т.е. мысли о сохранении прошлого Аля будущего. Автор делает заключение, что мировоззрение индивидуума и общества стало расширяться не только в философском плане, но также культурологическом и искусствоведческом. Постепенно понимание не только самой сути сохранения культурного наследия, но и его процессов и закономерностей, привели к тому, что стало формироваться отдельное направление мировоззрения, которое требует нового названия и определения - кАирономическое.

Ключевые слова: мировоззрение, клирономия, клирономическое мышление, историко-культурное наследие, сохранение культурного наследия.

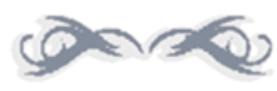

\section{Введение}

Сохранение историко-культурного наследия цивилизации является наиболее актуацьным и приоритетным направцением развития мирового сообщества в целом и общества каждого государства в отдельности. Невозможно представить прогресс человечества без понимания его первоисточников и развития культуры на протяжении всех стадий (эпох) формирования современного облика социума. ПоА современным Аля каждого момента времени состоянием общества необходимо понимать результат изменений Аанного социума на протяжении всего его эволюционирования в темпорацьном измерении.

Культурный облик общества не может быть сформирован из ниоткуда, с чистого миста. Это - результат многовековых трансформаций, Аиффузий и взаимопроникновений семиотических рядов, траАиций, фольклора, по своей сущности формирование нематериального культурного наследия и его переноса в материальную оболочку, что начинает формировать понятие ценности наследия, сначала в экономическом восприятии (эквиваленте), а затем и Ауховном - ценности прошлого Аля общества в будущем.

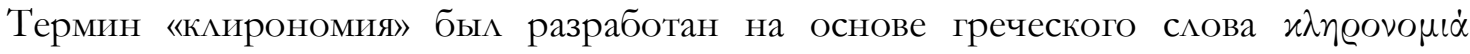
[klirənom ' ла] или [клирономйа], что в переводе означает в буквальном смысле «наследие». Наследием называются явления культуры и быта Аюдей, оставшиеся от прежних времён. Следовательно, использование Аанного греческого слова применительно к названию всей науки о сохранении историко-культурного наследия яв яется правомерным и Аогичным. КАирономическое мировоззрение также имеет право быть использовано как отдельный термин. Мировоззрение означает систему взглядов, оценок и образных представ ений о мире и месте в нём человека, общее его отношение к окружающей действительности и самому себе, а также обуслов енные этими взглядами основные жизненные позиции мюдей, их убежАения, идеалы, принципы познания и деятельности, ценностные ориентации (Буйчик, 2019в). Следовательно, клирономическое мировоззрение - это систему взглядов, оценок и образных представ ений о историко-культурном наследии и осознание роли человека по отношению к нему, общее его отношение к окружающим объектам, предметам и элементам историко-культурного наследия, а также обусловленные 
этими взглядами основные жизненные позиции, убежАения, иАеалы, принципы познания и деятельности, ценностные ориентации.

Историко-культурное наследие подразумевает под собой обязательно сохранение и нематериального, и материального Ауховного наследия. В Аанной мини-монографии использованы материалы первых двух глав книги «КАирономия - наука о сохранении культурного наследия», вышедшей в 2019 году в Германии и Франции на русском и английском языках, в которых раскрывается характер и эволюция формирования понятия «культурное наследие», что послужило в Аальнейшем фундаментом Аля разработки новой науки.

\section{1. Эмпирический характер сохранения культурного наследия}

Историко-культурное, или культурное, наследие - это часть материальной и нематериальной культуры, созАанная прошлыми поколениями и кАирономический базис общества (Буйчик, 2018). В Аанном параграфе рассматривается темпоральное изменение в кАирономическом мировоззрении общества относительно историко-культурного наслелия прошлых цивилизаций, которое формирует уровень общества.

На протяжении последних 12 тысяч мет истории человечества было созАано большое количество рисунков, строений, статуй и предметов быта. Наскальные изображения мы находим в гротах и пещерах, заселение которых происходило десятки тысяч мет назаА. Осенью 2014 года на острове Сулавеси археологи обнаружили предположительно Аревнейшие петроглифы в истории развития человечества, которым порядка 40 тысяч Ает (Самыге древние наскальныге рисунки обнаруженыг в пешере в Индонезии, 2014). Первые городские поселения, Аатировки которых официально признаны археологами, относятся к 8-му тысячелетию до н.э. Среди них особо выделяют поселение Иерихон, или Ариха на иврите, находящийся на Западном берегу реки ИорАан, первые следы жизни Аюдей в котором как раз относятся к Аанному периоду времени, а Аревнейшие городские укрепления датируются не позднее 6800 года до н.э., т.е. началом 7-го тысячелетия до н.э. (Strutin, 2001).

Иерихоном по возрасту постройки городских сооружений соперничает Аамаск, современная столица Сирийской Республики. Раскопки в предместье Тель-Рамад указывают, что территория современного Аамаска была заселена уже в 10-9-м тысячелетиях до н.э. (Neolithic Tell Ramad. Pre-History and Archaeology Glossary, 2001), т.e. существует вероятность, что именно Аамаск явАяется древнейшим городским поселение на планете, хотя вплоть до нашествия арамеев около 1400 года до н.э. он не был Аостаточно важным населённым пунктом региона. Также среди самых древних постоянных поселений человека называется город Библ, территория которого была заселена уже в 7 тысячелетии до н.э., но как городское поселение известен только с 3-го тысячелетия до н.э. (Neolithic Tell Ramad. Pre-History and Archaeology Glossary, 2001). Ещё одно поселение - Гобекли-Тепе, обнаруженное в 1994 году - по археологическим данным также было построено примерно в 7 тысячелетии до н.э. (Moscati, 2001), но насколько крупным бы этот город в тот период, пока остаётся открытым вопросом.

ОАнако среди археологов, историков, культурологов и искусствовеАов иАёт многолетний спор, что именно считать историко-культурным наследием прошлого. 
Аатировка относительно недавних объектов - зАаний, скульптур, предметов Аекоративноприкладного искусства и живописи - регулируется законодательством отдельных государств и ЮНЕСКО. К объектам культурного наследия (памятникам истории и культуры) народов Российской Федерации относятся объекты недвижимого имущества (включая объекты археологического наследия) и иные объекты с исторически связанными с ними территориями, произведениями живописи, скульптуры, Аекоративноприкладного искусства, объектами науки и техники и иными предметами материаАьной культуры, возникшие в результате исторических событий, преАставАяющие собой ценность с точки зрения истории, археологии, архитектуры, градостроительства, искусства, науки и техники, эстетики, этнологии или антропологии, социальной культуры и являющиеся свидетельством эпох и цивилизаций, подлинными источниками информации о зарождении и развитии культуры (Федеральныци закон от 25.06.2002 №73Ф3). ОАнако определение важности объекта или предмета прошлого остаётся абсолютно субъективным, на усмотрение экспертной комиссии при профильном министерстве каждого государства. Те объекты и предметы прошлого, которые определены как историко-культурное наследие, ранжируются по значимости - всемирного, национального и регионального значения.

Если на современном этапе развития общества, начиная с момента принятия МежАународным советом музеев в 1931 году Афинской хартии, имеется большое количество регламентирующих Аокументов, определяющих сущность и категорию объекта или предмета культурного наследия, то на протяжении Аесятков веков наследие прошлого определялось в различных цивилизациях по-разному.

Первым официально известным фактом сохранения объекта как определённой социальной, политической или культурной ценности цивилизации, т.е. неким исторически подтвержАённым фактом зарождения клирономического мировоззрения человека, является сообщение о восстановлении из песков Большого Сфинкса в долине Гиза. Первое упоминание о работах над Большим Сфинксом относится примерно к 1400 году Ао н.э. На стеле эпохи правления Тутмоса IV, возведённой межАу Авумя мапами Большого Сфинкса и сохранившейся до наших Аней, сохранилась наАпись, что царский сын Тутмос отправился на охоту в Аолину Ажейранов, гАе Хор-эм-Ахт заговориц с ним во сне и спросиц от мица Хармахиса освободить его от песка. Сфинкс преАложиц освободить его от песка в обмен на корону Верхнего и Нижнего Египта. К тому периоду монумент почти полностью был погружён в пески, что по Аанным палеоклиматических исследований могло произойти не менее, чем за 1000 мет запустения объекта. Это говорит о том, что сам Большой Сфинкс был создан не позже 2500-2400 годов Ао н.э. (Буйиик, 2014a).

Смысл стелы Тутмоса IV заключался в том, что он освободиц объект от песка, очистил его, привёл в надлежащий виА и, тем самым, спустя короткое время стал очередным фараоном. Археологические Аанные подтверждают, что Тутмос Аействительно провёл крупномасштабную и Аорогостоящую работу. Сохранившиеся остатки стен из кирпича-сырца с надписью имени «Тутмос» Аоказывают, что восстановительные работы велись согласно именно информации на данной стеле. Также сохранившиеся блоки были аналогичны тем, что использовались Хефреном при 
строительстве Аамбы, что сужает исторические рамки и Аоказывает правдивость имеющейся информации на стеле.

Таким образом, первые известные человечеству реставрационно-консервационные работы клирономического характера в период правления фараона Тутмоса IV состояли из трёх основных этапов:

1. Очистка монумента от песка. Вероятно, Большой Сфинкс был очищен полностью, а не частично, не смотря на утверждения некоторых источников. Это было важно не только с точки зрения восстановления всего облика божества, но и с позиции величия в асти и культа.

2. Постройка защитных саманных стен вокруг Большого Сфинкса с целью его защиты от физического воздействия ветра и песка. БАагодаря стенам монумент проАлил своё существование, хотя ветровая и механическая эрозия продолжались, пусть и в меньших объёмах. На сегодняшний день считается спорным, в каком виде Большой Сфинкс сохранился бы мучше - под песками или за стенами.

3. Восстановление поврежлённых частей монумента: возвращение в объём монумента отколовшихся частей, скреплённых цементирующим составом (Буйчик, 2014а).

Это был наглядный пример реставрационных работ, т.е. комплекса клирономических мероприятий. Фактически, на сегодняшний день дата 1400 года Ао н.э. может считаться самым древним документально обоснованным упоминанием о реставрационных работах, что значительно отодвигает историографию научно-практического течения.

ОАнако на протяжении всей истории крупнейших цивилизаций планеты понятие сохранения ценностей прошлого и их разрушение находились в некоей симметрии. Фактически, сохранение и вандализм в различных их формах сосуществовали во всех эпохах развития человечества, являя собой борьбу противоположностей: клирономии и вандализма. Аревнеегипетские фараоны обрушивали свои войска на территории Нубийского царства, грабя и уничтожая многочисленные храмы, что ответно Аелали правители самой Нубии. Несмотря на обоюдный вандализм, правители древнейших царств - Аревнего Египта, Нубии, Шумеро-Аккадского царства и Ар. - вели противоречивую политику и относительно объектов своего историко-культурного наследия, уничтожая стелы, статуи и фрески некоторых прошлых неугодных Аля внутренней политики правителей, и в то же время, заботясь о наиболее значимых монументах, имеющих сакральный смысл Аля цивилизации. Также имеются сведения о восстановительных работах в Аревнеегипетских и шумеро-аккаАских городах.

Следовательно, уже в эпоху Аревнейших царств уже существовало условное клирономическое понятие консервационно-реставрационных работ, которые исторически тесно сосеАствовали с вандализмом.

Сам термин «вандализм» был сформулирован в конце XVIII века. И относится ко времени Великой Французской революции. Аанный термин впервые в современном значении использовал в своём «Докладе о разрушениях, творимых вандализмом, и средствах их предотвращения» член Национального конвента аббат Анри Грегуар в 1794 году (Din-i Ilahi. Britannica Online Encyclopedia, 2013), призвав к принципиальному пресечению попыток уничтожения памятников искусства. Сам термин происходит от названия восточногерманского союза племён вандалов, разграбивших Рим в июне 455 года и не 
имевших никакого отношения к племенам вендов, западных славян, информация о чём стала устойчивым клише с VIII века, когда она ошибочно или намеренно появилась трудах западноевропейских хронистов (Francovich, 2002). Вандализм - это одна из форм Аеструктивного девиантного поведения человека, в ходе которого уничтожаются или оскверняются предметы искусства, культуры.

Английские источники обращают внимание на правовой аспект вандализма:

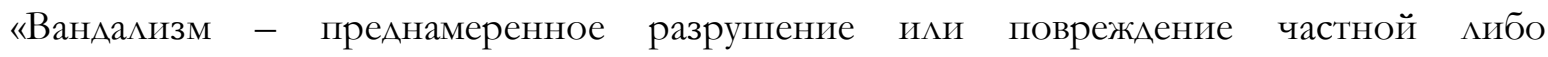
общественной собственности» (Oxford Living Dictionaries. Oxford University Dictionary, 2017). Согласно Энциклопедическому словарю Брокгауза и Эфрона: «Вандализм - Аикий беспощаАный грабеж, варварство» (Брокгауз, 1993).

Вандализм относительно разрушения объектов прошлого разцичной историкокультурной ценности можно классифицировать, используя мотивационную типологию вандализма С. Коэна:

- способ приобретения;

- тактический;

- илеологический;

- мщение (Coben, 1973).

Практика вандализма была свойственна не только племенам вандалов и варваров, которые в силу диаметрально противоположных взглядов на религию не воспринимали ценности античности Аревней Греции и Аревнего Рима. Особо ярким примером вандализма можно считать неприятие арабов-мусульман иных культур. В 641 году Халиф Умар ибн аль-Хаттаб повелел полководцу Амру ибн аль-Асу сжечь Александрийскую библиотеку, уточнив: «Если в этих книгах говорится то, что есть в Коране, то они бесполезны. Если же в них говорится что-нибудь Аругое, то они вредны. Поэтому и в том, и в Аругом случае их надо сжечь» (Богуславский, 2006). Если первый известный факт сожжения А^ександрийской библиотеки войсками Юлия Гая Цезаря в 47 гоАу Ао н.э. можно отнести скорее к категории «случайности», т.к. целью захвата города были верфи и склады с хлебом, то разграбление города в 216 году войсками императора Каракалмы уже относится к способу приобретения, а вандализм арабов-мусульман - к идеологическому.

ИАеологический вандализм на почве исламского религиозного фанатизма является наиболее ужасающим среди прочих. В большинстве случаев результатом такой формы вандализма является полная потеря объектов и предметов историко-культурного наследия. Примером могут считаться:

1) разрушение в 2001 году гигантских Аревних статуй Будыы в Афганистане и экспонатов Национального музея в Кабуле силами террористического Авижения Талибан;

2) уничтожение в 2014-2016 годах археологических памятников Аревних городов Пальмира, НимруА, Хатра, памятников шумерского, ассирийского и вавилонского искусства, хранившихся в музее города Мосул боевиками террористического Авижения «Исламское государство Ирака и Аеванта», в последующем - ИГ. 
ИАеологический ванАализм на почве фашисткой илеологии также показал крайние формы неприятия историко-культурного наследия, которые перемежались со способом приобретением в форме изъятия и присвоения чужого наследия. В ходе Второй мировой войны немецкими войсками были уничтожены и разграблены десятки Аворцовопарковых ансамблей и тысячи объектов культурного наследия в Восточной Европе и на территории западных республик

Советского Союза, в том числе большинство объектов Аеревянного зодчества, Аворцы и соборы Варшавы, Праги, Киева, Смоленска, пригородов Аенинграда (ныне Санкт-Петербурга). Ао сих пор не найдены компоненты уникальной Янтарной комнаты, знаменитого шедевра искусства XVIII века, вывезенного фашистскими офицерами из Большого Екатерининского дворца г. Пушкина (Санкт-Петербург).

Аолгое время, в эпоху Средневековья и Возрождения, отношение к историкокультурному наследию было равнодушным. Зачатки клирономического мировоззрения общества угасли. Мы можем видеть сотни картин голмандских, немецких, французских и итальянских художников XV-XVIII веков, на которых изображены красочные пейзажи и сцены из жизни различных слоёв населения на фоне руин прошлых эпох, в основном, Аревнеримских и Аревнегреческих строений и статуй.

Отсутствуют и документальные подтверждения каких-либо масштабных мероприятий по сохранению или восстановлению объектов кроме начала реставрации в 1565 году фресок Сикстинской капелАы спустя 53 года после их создания. Объекты и предметы наследия, в основном, не уничтожались, а оставлялись в забвении, что может интерпретироваться как некая форма идеологического вандализма. Учитывая, что в VVIII и XV-XVIII веках наблюдались малые цедниковые периоды, которые сопровожАались нестабильными кАиматическими условиями и общим похолоданием на территории Европы, необходимо отметить, что подавАяющее большинство объектов получили невосполнимый урон и практически были утеряны Аля будущих поколений.

В эпоху Средневековья произошла резкая смена ценностей в отношении к античной культуре. В 529 году император Юстиниан закрыл Платоновскую академию в Афинах, которая просуществовала около 900 мет. Запрет выплачивать жалованье учителям риторики и грамматики привёл к Аостаточно быстрому закрытию большинства школ афинского типа. Также стремительно стали закрываться языческие храмы, их имущество отбиралось в пользу казны. Фактически материальное историко-культурное наследие античности проходило сложную и комплексную нематериальную трансформацию, аАаптируясь к доктрине христианства. На повседневном уровне, например, произошла постепенная трансформация языческих праздников, переименованных на христианский ^аА - Новый гоА, Масленица и Аругие. Трансформационные процессы претерпели и «свободные искусства» античности - грамматика, диалектика, риторика, арифметика, геометрия, астрономия и музыка. Светские знания в СреАневековье признавались второстепенными, подчинёнными изучению Библии и христианской Аогматики. Особенно неприемлемым считалось эстетическое воспитание, объявленное «Ауховной мерзостью». Фактически, те клирономические воззрения, которые составцяли базис нематериального историко-культурного наследия античности, искусственно и методично искоренялись. 
Следовательно, можно считать, что в эпоху Средневековья ранее христианство, занимая непримиримую позицию к «языческой» античности само использовало инструменты вандализма - в буквальном и условном понимании. Внутри Европы нематериальное историко-культурное наследие прошлого трансформировалось, а материальное - игнорировалось или уничтожалось, например, многочисленные труды античных философов. ОАнако за пределами Европейского пространства христианские миссионеры и крестоносцы вообще не отличались гуманизмом и не ограничивались простым игнорированием «чужого» культурного наследия. Во время крестовых походов, начавшихся после объявления папой Урбаном II на Клермонском соборе 1095 года политики возвращения Святой земли, было сожжено множество храмов, разрушены Аесятки крепостей.

Например, во время Первого крестового похода спускаясь по реке Аунай, участники разграбили и опустошили венгерские земли, а затем занялись вандализмом в Константинополе. В общей сложности, за 350 мет, с 1096 по 1444 годы, был организован 21 крестовый поход, в результате которых, в основном, Юго-Восточная Европа и БАижний Восток потеряли множество предметов историко-культурного наследия населявших эти территории народов.

Эпоха Возрождения, или Ренессанса, ознаменовалась новой культурной парадигмы, возникшей в следствие кардинальных изменений общественных отношений в Европе и их переосмыслением. Понятие «ВозрожАение» ввёл итальянский живописец и историк искусств XVI века Ажорджо Вазари (Брокгауз, 1993), который в 1550 году в своём труде «Жизнеописаниях знаменитых живописцев, ваятелей и зодчих» отозвался о преАставитеАях итальянского искусства своей эпохи как о АюАях, которым удалось возродить античные традиции, «низвергнутые Ао крайней своей погибели» (Тучков, 2016).

Аанная эпоха подразделилась на 4 периода:

1) Проторенессанс, или Позднее Средневековье (2-я половина XIII в. - XIV в.);

2) Раннее Возрожление (XV в.);

3) Высокое Возрождение (первые 20 мет XVI в.);

4) Позднее Возрожление (середина и конец XVI в.).

В искусстве возвращение к ценностям античности происходит только в XV веке, поэтому Проторенессанс никак не повлиял на европейские цивилизации с точки зрения переоценки культурного наследия. К тому же, до середины XV века продолжались Крестовые походы, и влияние христианской церкви на социальную и духовную жизнь Европы была крайне велика. Хотя условно начало эпохи Возрождения относят к Пасхе 8 апреля 1341 года, когда сенат Рима за заслуги в искусстве наградил лавровым венком Франческу Петрарку, однако это был Аишь эпизод, который скорее служил исключением в период Проторенессанса, чем закономерным венцом трансформаций, начавшихся во 2-й половине XIII века с расцветом готической архитектуры.

Эпоха Возрожления не принесла фундаментальных изменений во взгляды общества на историко-культурное наследие. Если быть точнее, то в архитектуре, скульптуре, а затем и живописи стали только применяться достижения искусства античности. ОАнако к самим объектам и предметам культурного наследия прошлого в Европе ещё Аолгое время оставалось нейтральное отношение. Особо контрастировацо с илеалами Ренессанса 
поведение конкистадоров и первых поселенцев в Центральной и Южной Америке относительно культурных ценностей местных народов - майя, ацтеков, инков. Варварство и открытый вандализм испанцев, как откровенная форма антиклирономического воззрения, привели к тому, что Аревние цивилизации были разграблены, их многочисленные ценности мибо присвоены, т.е. вывезены в Европу, мибо бесследно исчезАи.

Фактически, Тодессильясский договор 1494 года узаконил изъятие Аюбых ценностей цивилизаций Нового Света в пользу испанской казны. Хотя Филипп II в 1573 году изАал «Ордонанс о новых открытиях», в котором наложил прямой запрет на Аюбые грабежи, насильственное обращение в христианство, однако по своей сути документ не защища народы Америки от самого изъятия ценностей. Пиратство и штормы стали элементами исторической потери части вывезенного культурного наследства индейских народов.

П^емена майя, ацтеков и инков стали приходить в упадок, терять своё нематериальное историко-культурное наследие, которое накапливали и сохраняли веками, города приходили в упадок и запустение. На протяжении последующих веков вплоть до ХХ века никто не интересовался заброшенными городами с точки зрения науки и восстановления наследия.

В Аальнейшем принципы варваризации были успешно заимствованы и применены и португальцами при колонизации территории современной Бразилии, и англичанами при захвате территорий Северной Америки.

В исторической ретроспективе эпоха Ренессанса показала, что с «высот художественных Аостижений Возрождения, составляющих золотой фонА общечеловеческого наследия, социально-экономические Аостижения, превзойденные

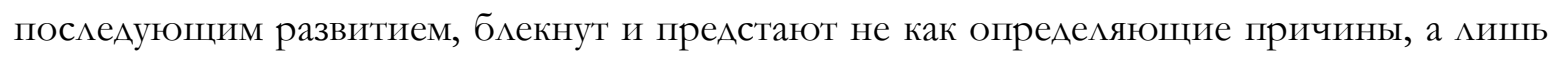
как сопутствующая внешняя среда» (Сунягин, 1985). Это отразилось и на отношении к историко-культурному наследию: возродились клирономические взгляды.

Строительство новых соборов, храмов, церквей, зАаний велось всё убыстряющимися темпами, богатеющие кланы ринулись в гонку за позиционированием своего капитала заказами на статуи, картины, отделку интерьеров. Например, знаменитая и одна из самых богатых семей Европы - Медичи - за 300 мет своего процветания финансировала строительство таких объектов, как:

- 3-х Аворцов - Палаццо Веккьо скульптором и архитектором Арнольфо Аи Камбио (1299-1314 гг.) (Tomasi, 2007), Палаццо Медичи-Риккарди архитектором и скульптором Микелоццо ди Бартоломео (1444-1460 гг.) (Ferrara \& Quinterio, 1984) и Палаццо архитектором и скульптором Питти Филиппо Брунелмески (1458-1464 гг.) (Kox, 2005);

- 2-х капел - Медичи в церкви св. Аннунциаты тем же М. ди Бартоломео (Oesterreich, 1774) и Новой Сакристии в церкви Сан-Аоренцо Микеланджело Буонарроти (Erpel, 1990);

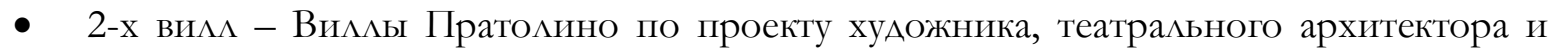
сценического оформителя Бернардо Буонталенти Вилмы Медичи в Риме в исполнении архитектора и скульптора Бартоломео Амманати (1576 г.) (Брокгауз, 1993). 
Необходимо заметить, что все вышеперечисленные архитекторы были очень знамениты и являлись ведущими в итальянской школе. Также семья Медичи привлекала Аля заказов живописных полотен, барельефов и скульптур таких именитых мастеров как:

- Андреа дель Верроккьо - налгробие Козимо Медичи (1465 г.), скульптурная группа «Уверение Фомы» (1476-1483 гг.), гробница Пьеро и Ажованни Медичи, эскизы штандартов и рыцарских Аоспехов Аля турниров Аоренцо Медичи, скульптура «Мальчик с Аельфином» Аля фонтана виллы Медичи в Кареджи (Азуффи, 2008);

- Сандро Боттичелли - роспись знамени Аля Ажулиано Медичи, картина «Поклонение волхвов», среди изображённых - преАставители рода (1475-1478 гг.), портрет Ажулиано Медичи, «Паллада и кентавр», «Весна» и Аругие (Зарничкий, 2007);

- Беноццо Гоццоли - росписи фрески в Палаццо Медичи-Риккарди (Азуффии, 2008);

- $\quad$ Аука Ажордано - фрески в палаццо Медичи-Риккарди (Вазари, 2017);

- Понтормо (настоящее имя Якопо Каруччи) - росписи вилмы Медичи в Поджо-аКайано (Аетmа, 1999).

Как видно из списка творцов, работавших на членов семьи Медичи, в эпоху Возрождения привлекались огромные средства из накоплений богатейших кланов на создание нового, но не на восстановление или хотя бы подцержание старого. Всё это порожАало фонА будущего богатого историко-культурного наследия, но не способствовало зарожАению именно научного кАирономического понимания сохранения наследия прошлого. Архитекторы, скульпторы и живописцы Ренессанса с большим энтузиазмом обращались к Аостижениям искусства античности, но только это, не более. Подражание и копирование не ассоциировалось с возможностью восстановления имевшегося фонда объектов и предметов античности и более ранних эпох.

В XI-XIV веках подобное отношение прослеживается практически во всех государствах Европы, включая Русь. Анализ состава каменных стен средневековых крепостей и церквей Великого Новгорода, Пскова, Киева и ряда других городов показывает, что, естественно, ремонтно-восстановительные работы велись на всём протяжении веков, но они также носили характер мишь буквального подцержания объектов в АОлжном состоянии. Часто ремонт производился абсолютно Аругими материалами и методиками, что больше походило на вынужденные минимальные Аействия по удержанию объекта в сохранности, чем на реставрационные работы.

В этот период входит в практику создание картинных галерей в зАаниях, которые были специально возведены Аля этого или хорошо подходили по своим художественноархитектурным достоинствам. Семья Медичи, например, тратила на создание галерей большую часть своей казны. В 1582 году зАание, построенное Аж. Вазари в 1565 году Аля административных офисов, было отведено под знаменитую ныне галерею Уффици (Фосси, 2013). 3Аание Уффици соединяется посредством Старого моста (итац. - Ponte Vecchio) с Аругой знаменитой галереей - Питти. Подобные галерейные комплексы стали возникать и в других городах Апеннинского полуострова - Пизе, Сиене, Вероне, Венеции - и позже в крупных городах Европы - в Германии, Франции, Испании, Нидерландах, Швеции и Англии. 
Следовательно, все эти галереи создавались во имя сохранения уже имеющихся предметов историко-культурного наследия - живописи и скульптуры, - что можно считать основанием Аля объявления конца XVI - начала XVII века началом масштабной Аеятельности по сохранению некоторых видов объектов историко-культурного наследия: живописных картин, фресок, скульптур и ряда предметов декоративно-прикладного искусства, т.е. предтечей формирования кАирономического мировоззрения. Аанный виА сохранения не был пока осмысленным относительно консервации, т.к. предметы и объекты не требовали экспертного вмешательства в силу своей относительной временной новизны и хорошего состояния. Ао наших Аней не сохранились какие-либо документальные подтверждения реставрации полотен или скульптур, которые были повреждены во время экспозиции в галереях на протяжении XVI-XVII веков. Вполне вероятно, что такие работы проводились, но Аибо тайно, Аибо настолько эпизодически и без АОлжного профессионального подхода, что не были удостоены внимания хранителей данных галерей в их отчётах.

Эпоху Ренессанса через религиозную реформацию (Бадак и Ар., 2002) сменило Просвещение, которое определяется в рамках конца XVII - всего XVIII века. ОАнако именно периол религиозной реформации (XVI в. - 1-я пол. XVII в.) становится переломным и значимым в деле истинного сохранения культурного наследия прошлого в Европе. Как уже говорилось выше, первые документально известные реставрационные работы эпохи Возрождения были проведены с фресками Сикстинской капелмы в 1565 году, именно в конце Ренессанса.

В Аальнейшем, спустя 160 мет, в 1726 году, в эпоху Просвещения, художником Микеланджело Белмотти была предпринята первая попытка восстановить картину выдающегося живописца и учёного Аеонардо Аа Винчи «Тайная вечеря». Уже в 1729 году была описана реставрационная работа Аоменико Микелини в Венеции с полотнами Тициана. Именно тогда реставрация начинает определяться как профессиональное направление, и сама профессия «реставратора» становится более значимой. Во второй трети XVIII века она уже становится отдельной профессией во Франции, что можно считать важным историческим фактом в формировании клирономического мировоззрения. Почти 85 мет, с 1735 по 1820 годы проводилась реставрация картин Испанской королевской галереи после пожара 1734 года (Iglesias, 1991). Сотни ценных картин уже были обработаны согласно особой разработанной методики в специально построенной студии. Захира Велиз смог задокументировать используемые при работе материалы (Sitwell \& Staniforth, 1998), чем помог Аифференцировать историю развития направления клирономии, т.е. сохранения историко-культурного наследия на тот момент на три этапа:

1) Аревний - эпоха Аревнейших и Аревний цивилизаций, заканчивающаяся Античностью, в которых проводилась нерегулярная эпизодическая восстановительная работа над объектами культурного наследия (Аворцами, храмами, крепостями) без осознанного восприятия наследия прошлого;

2) варварский - эпоха Средневековья и Возрождения, когда разрушение и присвоение объектов культурного наследия прошлого преоблаАало наА их игнорированием; 
3) новый - период религиозной реформации и эпоха Просвещения, когАа появилось осознание сохранения имеющихся уже объектов и преАметов наследия прошлого Аля потомков с целью их позиционирования и началось научное осмысление консервационных и реставрационных методов сохранения.

В третий период истории сохранения объектов и предметов историко-культурного наследия начинается интенсивное развитие наук - физики и химии, - которые способствуют осознанию научного подхода к консервационно-реставрационным работам. Среди особо значимых и задокументированных мероприятий в области реставрации и консервации XVIII века, кроме вышесказанных, можно выделить следующие:

- $\quad$ 1743-1780 годы - в Эрмитаже Аукасом Конрадом Пфандцельтом проводятся первые реставрационные работы в России - техническая реставрация масляной живописи (Aлешин, 1989);

- $\quad$ 1750-1815 годы - работа Мауро Наталь и Аоменика Пуло по реставрации картин в Центральном музее искусств Парижа (Noemie, 2010);

- 1774 гол - Матиас Эстеррайх публикует каталог картин из колмекции прусской короны (Oesterreich, 1774), который в Аальнейшем использует Аенон при выборке предметов, подлежащих реставрации (Noеmie, 2010);

- 1777 и 1785 годы - Аиректор реставрации общественных картин Венеции и Риальто Пьетро ЭАварас опубликовывает основные концепции превентивной консервации, типичные ошибки при подборе материалов, а также основы уважения к авторству и обратимости (Doerner Institut, 2019);

- 1794 гол - американский живописец Чарльз Уим^сон Пил в своей публикации описывает использование воска Аля пропитки полотна; Аанная методика позволила к середине XIX века защитить воском многие картины известных галерей Европы (Buychik, 2017b).

Следовательно, XVIII век стал основополагающим этапом формирования консервационно-реставрационной Аеятельности по сохранению историко-культурного наследия прошлого, иначе говоря, формирования клирономического мировоззрения общества. Мы ещё не наблюдаем внимания и заботы человека об объектах и предметах Аалёкого прошлого - Аревнейших цивилизаций и античности. ОАнако архивные Аокументы говорят о начале процесса заботы о сохранности объектов и предметов относительно недалёкого прошлого - последних 200-300 Ает, т.е. эпохи Возрождения. По-прежнему, базируясь на идеалах искусства античности, ни его творцы, ни специалисты в формировавшейся области сохранности предметов искусства, ни их заказчики из категории обеспеченных представителей общества не акцентировали внимание на восстановлении более ранних предметов и объектов искусства.

Эпоха Просвещения ознаменовалась выходом понимания сохранения историкокультурного наследия прошлого на новый уровень - научно-познавательный кАирономический. Это Ааёт повод выделить четвёртый этап в его истории и развитии. Аанный этап может быть определён временными рамками начала XIX - нача^а XX века. 
Эти 110-120 ^ет необходимо разделить на два вектора развития работ по сохранению наследия прошлого:

1) вектор познавательный - ведутся масштабные поисково-исследовательские работы на территории Южной Европы и Северной Африки;

2) вектор научный - проводится большое количество исследований в области физик и химии материалов, которые способствуют открытию новых эффективных способов сохранения и восстановления предметов и объектов наследия.

Среди поисково-исследовательских проектов XIX века в области археологии необходимо выделить:

- $\quad$ работу британских и французских учёных, открывших западному миру роскошные Аворцы поздне-ассирийского царства с уникальными барельефами, изображающими сцены охоты, боёв, культовых Аействий;

- расшифровка Розеттского камня французским египтологом Жаном Француа Шампольоном (Брокгауз, 1993; Parkinson et al., 1999);

- находку Королевской библиотеки Ашшурбанипал, одной из Аревнейших в мире, в городе Ниневии в середине XIX века (Grayson, 1980; Russell, 1991);

- в 1861 году французским путешественником Анри Муо открыт Ангкор-Ват грандиозный памятник будцийского искусства Камбоджи (1113-1150 гг.), часть комплекса индуистских и будАийских храмов IX-XIII веков, известных поА общим названием Ангкор (Petrotchenko, 2011);

- открытие в 1870-е годы немецким археологом-самоучкой Генрихом ШАиманом мегендарного города Троя (Штоль, 1991; Traill, 1995);

- в 1874-1876 годах в ходе раскопок, начатых немецким археологом Генрихом ШАиманом, были найлены шахтные гробницы Микенского царства (Ванденберг, 1996; Hogarth \& Schliemann, 1910-1911);

- исследования на острове Пасхи и находку письменности ронгоронго (Фёдорова, 2001);

- исследования российских учёных в Западной Сибири в конце XIX века и находку самой Аревней в мире Аеревянной скульптуры

- $\quad$ возрастом примерно 11 тыс. мет - шигирского илола (Савченко, 2004);

- исследования британского египтолога Говарда Картера в Аолине царей в 1914-1922 годах (Kapmep, 1959; James, 2012).

Следовательно, поисково-исследовательские работы в XIX веке велись ведущими государствами Старого Света на большой территории, охватывающей западную и центральную часть Евразии.

Научная деятельность в области реставрации и консервации в XIX веке также стала проводиться высокими темпами. Как пример можно привезти ряд исторических фактов в хронологическом порядке:

- 1802 год - группа химиков и художников-реставраторов во главе с Хакеном и Роузером проводят перевод полотна Рафаэля «Мадонна из Фолиньо» и её реставрацию (Meuthen, 2010);

- 1809 год - граф Шапталь де Шантелу издаёт трактат о пигментах, использованных в Помпеях ещё эпохи Аревнего Рима (Gough, 1998); 
- 1812 гол - Ф. Бербер, антверпенский аптекарь применяет воскканифольный состав в своей реставрационной практике Аля фиксирования Аеформаций (Сфумато в живописи, 2018);

- 1813-1836 годы - проводится реставрация Кремлёвского комплекса после освобождения Москвы от войск Наполеона (Бакарев, 2012);

- 1851 год - проводится работа по защите полотна Рембрандта «Ночной Аозор» воском;

- 1852 год - художник Ажон Сегье авторским методом реставрирует 9 крупных полотен в Национальной галерее $\Lambda$ ондона;

- 1850-1853 годы - МайкА Фарадей проводит Аля Национальной галереи Мондона анализ на предмет воздействия тумана, смога, газов и освещения на изменение цвета поверхности покрытия, а также исследование маков и методов очистки (Hamilton, 2002);

- 1863 год - немецкий исследователь Макс Петенкофер запатентовывает метод «обратного старения мака» в результате воздействия паров этанола;

- 1868 гол - обнаружение пешеры Альтамира (Испания) с полихромной каменной живописью эпохи верхнего палеолита (Солютрейская культура) (Аэвлет, 2004; Madariaga de la Campa, 2000);

- $\quad$ 1870-е годы - Ауи Пастер проводит большой комплекс исследований макокрасочной и оптической кристаммографии (Брокгауз, 1993; Debre \& Forster, 1998);

- 1896 гол - Вильгельм Конрад Рентген первым облучает Х-лучами полотна (Храмов, 1983; Glasser, 1993).

Также на протяжении XIX века открывались специализированные маборатории, которые активно работали в клирономической области консервации и реставрации предметов историко-культурного наследия:

1) 1815 гоА - сэр Гемфри Аэви созАаёт переносную химическую мабораторию, в которой совместно с Майклом Фарадеем исследует пигменты (Храмов, 1983; Fullmer, 1969);

2) 1850 гоА - созАаётся первая стационарная химическая маборатория в области сохранения объектов культурного наследия в НьюЙорке, США (Oliver, 1865-1890);

3) 1888 год - Фридрих Рантген становится руководителем первой химической маборатории Королевских музеев Берлина (Buychik, 2017b).

Периол XVII-XIX веков ознаменовался рядом значимых мероприятий по учёту и сохранению значимых объектов и в Российском государстве. В конце XVII века по указу Петра Великого производятся обмеры и снимаются чертежи древних будаийских храмов в Сибири. Екатерины II издаёт указы об обмерах, исследованиях и учёте зАаний, имеющих историко-художественную ценность, а также о состав ении планов и описаний Аревних городов и о сохранении памятников археологии.

Активные попытки учета и охраны памятников старины и природы предпринимаются передовыми деятелями России уже в XVIII веке, например, архивные Аанные свилетельствуют о том, что в 1754 году жители Москвы и ближайших сёл и Аеревень обратились в Петербург в Берг-колмегию с жалобой и требованиями принять 
меры к защите их от бедствий, которые приносят железоделательные заводы, построенные и строящиеся в Москве и вокруг неё. Постепенно внимание к охране природного и культурного наследия значительно усиливается. В XIX веке принимались частные и общие государственные постановления, регламентирующие строительную и иные виды деятельности. Был разработан «Строительный устав», который запрещал снос или ремонт, ведущие к искажению зАаний, возведённых в XVIII веке. Важную роль в деле охраны природного и историко-культурного наследия играли общественные и научные организации: Московское археологическое общество, Русское историческое общество, Общество защиты и сохранения в России памятников искусства и старины и Ар. На съездах этих организаций обсужАали проблемы охраны историко-культурного наследия. Также в рамках своей деятельности они проводили следующие мероприятия:

- занимались разработкой законодательства по охране памятников;

- ставили вопрос о создании государственных органов Аля охраны культурноисторических ценностей.

Следовательно, на протяжении XVIII-XIX веков общество коренным образом трансформировало своё клирономическое восприятие историко-культурного наследия, обратив пристальное внимание на разработку научных подходов в области консервации и реставрации предметов живописи. Также начинается финансирование крупномасштабных исследований территорий древних цивилизаций на предмет поиска и фиксирования объектов и предметов культурного наследия Аревнейших, Аревних цивилизаций и эпохи античности.

Современный этап развития направления клирономии, или сохранения историкокультурного наследия прошлого, можно условно идентифицировать с 1918 года, когАа в Российском государстве была проведена конференция, посвящённая раскрытию Аревней живописи (Трочкая, 1924). 19-22 марта 1921 года проходила первая Всероссийская реставрационная конференция (ЦГАОРСС). Фактически, общество перешло от частных научных исследований к планомерному и регулярному обмену опытом. Вслед за Аанной конференцией, в 1923-1933 годы, проводилась четвёртая крупномасштабная реставрации Большого Сфинкса долины Гиза, которую возглавлял один из величайших египтологов первой половины XX века французский специалист Эмиль Барез (Буйчик, 2014а). С 1928 года стали проводиться МежАународные конгрессы по современной архитектуре (CIAM):

- 1928 год. Первый конгресс в г. Сарразе (Швейцария) и основание СІАМ;

- 1929 гол. Второй конгресс в г. Франкфурт (Германия), гАе обсужАались вопросы созАания минимально комфортного жилища;

- 1930 год. Третий конгресс в г. Брюссель (Бельгия), на котором поднимались проблемы рационального распределения земель;

- 1933 год. Четвертый конгресс в г. Афины (Греция), проведён анализ 33 ведущих городов и выработана Хартия градостроительства;

- 1937 год. Пятый конгресс в г. Париж (Франция), тема которого заключалась в понимании жилища как места отдыха;

- 1947 год. Шестой конгресс в г. БриАжуотер (Англия), где были подтвержАены основные цели СIAM; 
- 1949 год. Седьмой конгресс в г. Бергамо (Италия), на котором обсужАалось практическое применение Афинской Хартии и создание градостроительной моАульной сетки СІАМ;

- 1951 год. Восьмой конгресс в г. ХаАлесон (США), на котором обсужАались проблемы центральных районов крупных городов и мегаполисов;

- 1953 год. Аевятый конгресс в г. Экс-ен-Прованс (Франция), в рамках которого обсуждались результаты исследования жилища человека;

- 1956 год. Аесятый конгресс в г. Аубровник (Югославия), гАе также обсужАался вопрос исследования жилища человека (Глазвщев, 2008; Risselada \& Hewvel, 2005).

13-15 октября 1930 года в Риме прошла первая «МежАународная конференция по изучению научных методов Аля исследования и сохранения произведений искусства», в рамках которой были проведены многочисленные семинары, определены стандарты реставрационной практики, Аокументооборота и сохранения предметов и объектов культурного наследия (Буйчик, 20140). В 1931 году на съезде специалистов по охране памятников и исторических мест в Афинах (Греция) была принята знаменитая Афинская хартия, которая положила начало процессу глобализации проблемы сохранения историко-культурного наследия и ознаменовала современный этап развития кАирономического мировоззрения общества.

С 1934 года в Европе начинается подготовка специалистов в области консервации объектов и предметов культурного наследия:

- 1934 год - открытие курсов по консервации Аля подготовки специалистов в АонАОнском НИИ «КортолА»;

- 1936 год - открытие курсов по консервации Аля подготовки специалистов в Академии изящных искусств Вены;

- 1939 год - открытие курсов консервации Аля подготовки специалистов при Государственном институте технологического тестирования и исследования в области живописи «Аойрнер Институт»;

- 1949 год - открытие курсов по консервации Аля подготовки специалистов в Технологическом институте Малерай в Штуттгарте;

- 1952 год - первый выпуск специалистов по консервации МежАународного института консервации;

- 1959 год - начинает работу Римский центр обучения реставрации и консервации объектов культурологической значимости (ICCROM);

- 1970 год - в колмедже Куперстоуна (США) осуществлён первый выпуск бакалавров консервации;

- 2005 год - Университет Аос-Анджелеса ввёл в учебный план Аисциплину «Археологическая реставрация» (Buychik, 2017b).

Итогом создания целой сети образовательных учрежлений в Европе и США стала первая конференция Ассоциации профессионального образования по консервации в клубе ГарварАского университета в 1984 году.

Паралцельно проводилась интенсивная деятельность по разработке научной теоретической и практической базы: 
- в 1937 году открывается Государственный институт технологического тестирования и исследования в области живописи «Аойрнер Институт» (Doerner Institut, 2019);

- в 1939 году основывается Высший институт консервации и реставрации в Риме, задачей которого является выработка сводов и правиц охраны и сохранения предметов и объектов культурного наследия (La storia dell'Istituto. L'Istituto Superiore per la Conservazione ed il Restauro, 2013);

- в 1948 году в Брюсселе основан Королевский институт художественного наследия и проходит предварительная встреча специалистов по подготовке к созданию МежАународного института консервации (About KIK-IRPA. Royal Institute for Cultural Heritage);

- в 1950 году создан МежАународный институт консервации, ныне - МежАународный институт консервации музейных объектов (A brief history of IIC, 2015);

- в 1957 году в Центральном Римском Институте создаётся маборатория прикладной биологии, которая стала работать в области сохранения предметов искусств (Cultural Properties. World Heritage List. World Heritage Center. UNESCO);

- в 1960 году создаётся Американский институт консервации (American Institute for Conservation of Historic and Artistic Works);

- в 1963 году Чезаре Бранди публиккует «Теорию реставрации» (Brandi, 2011);

- в 1968 году опубликован Кодекса этики и стандартов практической консервации (Тhе Murray Pease Report. IIC-American Group, 2018);

- в 1976 году основан Исследовательский центр материалов в области искусства и консервации (Университет Карнеги, США);

- в 1991 году создана Европейская конфедерация организация консерваторов и реставраторов (ЕССО);

- в 1999 году создана Международная сеть по консервации предметов и объектов современного искусства (INCCA) (Buychik, 2017b).

В течение XX века был слелан ряд крупных научных разработок в области физик и химии материалов, которые внесли огромный вкцаА в развитие методов консервации и реставрации объектов и предметов культурного наследия:

- в 1931 году Ажеймс Роуример из Музея Метрополитен впервые использовал ультрафиолетовые кучи Аля проверки полотен;

- в 1932-1942 годах публиикация серии технических исследований в области изобразительного искусства Аля Музея искусств «Фогг»;

- в 1939 году группа межАународных экспертов в области сохранения предметов и объектов культурного наследия издаёт во Франции «Пособие по охране картин» (консервации);

- в 1940 гоАу эксперты в области истории искусств, реставрации и химии выпустили «Руководство по сохранению предметов живописи»;

- в 1955 году впервые было использовано вакуумное давление в горячем столе;

- в 1960 году англичанин Ажек Уицларл создал стол с вакуумным нагнетателем Аля повторной реставрации живописи; 
- в 1973 году Эндрю ОАли, главный консерватор Британского музея, провёл тест на определение безопасности материалов Аля артобъектов (ныне - «Тест ОАци») (Brandi, 2011).

Паралцельно на протяжении последних 100 ^ет по всему миру провидится огромное количество поисково-исследовательских и консервационно-реставрационных работ, среди которых необходимо выделить следующие:

- 1900-1930 годы - открытие и раскопки объектов минойской цивилизации на Крите британским археологом Артуром Эвансом;

- 1911 год - открытие американским учёным-историком из Йельского университета Хайрамом Бингемом Мачу-Пикчу - крепости инков, города-святилища XV-XVII вв. в Перу;

- 1922 год - открытие гробницы Тутанхамона британским археологом Говардом Картером;

- $\quad$ 1923-1933 годы - четвёртая реставрация пирамиды Хеопса (Хуфу);

- $\quad$ 1950-е годы - обнаружение Свитков Мёртвого моря;

- 1951 год - при раскопках в Новгороде в слоях XI-XV веков Новгородской археологической экспедицией АН СССР обнаружены Берестяные грамоты Аревнерусские тексты, процарапанные или продавценные на кусках березовой коры (бересты), уникальный источник по истории Аревнерусского языка, социальноэкономических и политических отношений;

- 1955-1987 годы - пятый этап реставрации пирамиды Хеопса (Хуфу) отАелом Египетских Аревностей Национального музея древностей в Каире;

- 1974-1984 годы - обнаружение и полномасштабные раскопки «Терракотовой армии», захоронения более 8.100 полноразмерных терракотовых статуй китайских воинов и их ^ошадей у мавзолея императора Цинь Шихуанди в Сиане (КНР);

- 1977 год - обнаружение экспертом по греческой археологии Манолисом Андрониксом места погребения македонских королей в Вергине;

- 1986 год - на северо-западном берегу Галилейского моря в Израиле обнаружена Галилейская Аодка - Аревнего рыболовного судна I века;

- 1993 год - в кургане скифского времени на алтайском плато Укок около границы России с Монголией экспедицией новосибирского археолога Натальи Полосьмак обнаружена принцесса Укока - мумия Аревней женщины, «принцессы ААтая»;

- 1993-1999 годы - шестой этап реставрации пирамиды Хеопса (Хуфу) по результатам межАисциплинарного симпозиума 1992 года в Каире;

- 1994 гол - открытие Аревнего поселения Гобекли-Тепе, которому примерно 9000 мет;

- 2009 год - в деревне Хаммервич в Аичфилде (Стаффордшир, Великобритания) была найдена колмекция золотых, серебряных и металмических предметов из колмекции англо-саксонской эпохи VII-VIII веков;

- 2015-2017 годы - реализуется проект ScanPyramids по сканированию методом мюонной томографии (Фараон и тайная комната, 2017). 
Следовательно, большое количество исследовательских проектов в сфере археологии, организация многочисленных курсов и выпускающих кафеАр по консервации и реставрации объектов историко-культурного наследия в ведущих университетах мира побудила исследователей разработать еАиную методологию изучения Аанного направления искусствоведческих и культурологических наук и вылелить кАирономические направления - консервацию и реставрацию - в отдельную науку.

В последние 100 мет активная работа в сфере развития направления сохранения объектов историко-культурного наследия ведётся и в российском государстве. Музейный отдел ЦГРМ ГАавнауки в период с 1918 по 1927 годы провёл серию экспедиций по разАичным территориям

страны с целью нахожАения и описания объектов и предметов историко-культурного наследия страны. В 1918 году при Отделе по делам музеев была организована Всероссийская реставрационная комиссия, преобразованная впоследствии в Центральные Государственные реставрационные мастерские (ЦГРМ). В 1921 году при Наркомпросе был создан Академический центр, в который входил ГАавный комитет по Аелам музеев и охране памятников искусства и старины (ГАавмузей). В том же году в советском государстве была организована Первая Всероссийская реставрационная конференция (Первая Всероссийская реставрачионная конферениия, 2018). На следующий гоА при Русском музее (г. Санкт-Петербург) была создана реставрационная мастерская, которая уже в 1935 году разделена на Ааборатории и сектора: живописи, новой живописи, скульптуры, прикладного искусства и народного. Там же в 1953 году была открыта мастерская реставрации графики, на следующий гоА - мастерская реставрации Аревнерусской живописи, а в 1961 году - мастерская реставрации деревянной скульптуры, Аекоративной резьбы и мебели и мастерская реставрации тканей.

Также на протяжении XX века, как и в XIX столетии, в российском государстве реализовывался большой комплекс реставрационных проектов, связанных как с восстановлением объектов и предметов культурного наследия после Первой и Второй мировых войн, но и в силу приоритетной важности сохранения культурного наследия территории страны. Из наиболее значимых реставрационных проектов необходимо выделить следующие:

- 1919 год - начата живописная реставрация в Великом Новгороде. Раскрыта значительная часть фресок в Успенском соборе (г. ВАадимир) на КАязьме, исполненных в 1408 году вместе с Аанилой Чёрным;

- 1929 год - в Богоявленском кафедральном соборе в Елохове (г. Москва) архитектор И.С. Кузнецов реставрирует живопись купола;

- 1950 год - реставрация росписи Кафедрального собора во имя Рождества Пресвятой Богородицы (г. Ростов-на-Аону);

- $\quad$ 1950-1956 годы - реставрация интерьера Казанского собора (г. Санкт-Петербург);

- 1953-1963 годы - реставрация Успенского собора (г. Ростов);

- 1962-1974 годы - реставрация Знаменского собора (г. Великий Новгород) под руководством Г.М. Штендера; 
- 1963-1968 годы - реставрация фасадов Казанского собора (г. Санкт-Петербург);

- 1966-1968 годы - Всесоюзные научно-реставрационные мастерские (BCHРМ) под руководством архитектора В.С. Баниге провели реставрационные работы в Соборе Софии Премуарости Божией (г. ВологАа);

- 1972-1994 годы - реставрация храма Воскресения Христова (Спаса-на-Крови) (г. Санкт-Петербург);

- $\quad$ 1974-1981 годы - реставрация живописи XII, XV, XVII, XIX-XX веков в Успенском соборе XII века (г. ВАадимир);

- 1974-1994 годы - реставрация фасадов и интерьеров Собора во имя первоверховных апостолов Петра и Павла (Петергоф, пригород Санкт-Петербурга);

- 1989-1999 годы - реставрация Спасо-Преображенского Собора (г. Нижний Новгород);

- 1993-1995 годы - реставрация древнего иконостаса Успенского собора Рязанского Кремля (г. Рязань);

- $\quad$ 1998-2000 годы - полномасштабная реставрация Троицкого собора (г. Екатеринбург), заново возведены купольные барабаны и колокольня;

- 1998-2007 годы - реставрация православного мужского Валдайского Иверского Богородицкого Святоозерского монастыря (г. Вацдай);

- 2004 год - реставрация Крестовоздвиженского собора Свято-Юрьевского монастыря (близ г. Великий НовгороА);

- 2004-2008 годы - реставрация мютеранской Кафедрального собора святых апостолов Петра и Павла (г. Москва).

Результатом большой работы государства в области сохранения объектов культурного наследия последние 100 мет стало создание в 2001 году. Союза реставраторов Санкт-Петербурга (первого объединения профессионацьных реставраторов в отдельном субъекте федерации), а в 2007 году Российской Ассоциации реставраторов.

Таким образом, эмпирические исследования истории сохранения человеком объектов и предметов историко-культурного наследия прошлого доказывают, что кАирономическое мировоззрение начало формироваться с развитием первых известным нам цивилизаций Месопотамии и Северной Африки, что прослеживается в многочисленных археологических изысканиях, подтвержАающих наличие в ШумероАккадском царстве и Аревнем Египте реставрационных работ. В последние 150 мет общество кардинально изменило своё отношение к наследию прошлого и стало применять научный подход к сохранению и восстановлению историко-культурного наследия. Изменение мышления, переход от игнорирования материального прошлого к его восторжению, а потом осознанию отсутствия вечности относительно состояния материи и стремлению сохранности прекрасного - всё это привело к практической реализации желания посредством научных кАирономических изысканий, создания методологии и организации образовательного процесса с целью выпуска профессиональных работников в области реставрации и консервации объектов и предметов историко-культурного наследия. Всё это в начале XXI века актуализировало 
создание нового единого научного направ еени - кАирономии, т.е. сохранения историкокультурного наследия.

\section{2. Сохранение культурного наследия в фимософской мысли}

Аля рассмотрения клирономии как научного направления сохранения историкокультурного наследия общества необходимо проследить эволюцию философской мысли о её роли Аля развития цивилизации.

Следствием становления качественно нового состояния культуры, определяемого взаимодействием культур отдельно взятых цивилизаций современной эпохой, явАяется освоение культурного контекста общего мирового пространства, осознание целостности и неделимости мира. Современный мир в последние 3-4 века всё больше приобретает черты глобального сообщества, что приводит к расширению взаимосвязей различных стран, народов и, следовательно, их культур. В связи с этим особенно важным представ яется осознание понятия «ценности» в области культуры, что в свою очередь формирует понятие «культурной ценности», а через него уже определение категории «культурного наследия», которое базируется на совокупности культурных ценностей, определённых каждой цивилизацией в рамках, принятых данным социумом ценностей.

Обмен культурными ценностями является существенным фактором развития культурно-творческого потенциала народов, интенсификации процесса взаимовлияния и взаимообогащения национальных культур. Сохранение культурного наследия прошлого, как своего, национального, так и всемирного, в том числе приобретённого, явАяется на сегодняшний день основной задачей человека. Преемственность кучших Аостижений художественного опыта позволяет рассматривать обмен культурными ценностями как объективную историческую закономерность. Кроме того, история обмена культурными ценностями - это особая часть истории культуры каждой страны и каждого народа.

Помимо культурной составАяющей, обмен культурными ценностями явАяется инструментом межАународной культурной политики, способствуя созданию условий Аля Аиалога и сотрудничества государств, народов, относящихся к разАичным культурным традициям. Ведь культурные ценности - произведения искусства, научное знание, культурные традиции - это достояние человечества. Они выше границ и национальных барьеров. Культурные ценности преАставляют собой тот ресурс культурного обмена, который может и должен быть использован в интересах гуманитарного сотрудничества во всём мире.

Культурные ценности, являясь высшими кАирономическими проявлениями мировой материальной и Ауховной культуры, концентрируют в себе многовековой опыт человечества. Они непосредственным образом выполняют преобразующую функцию по отношению к человеку и обществу в целом. Культурная жизнь общества включает наследие исторического прошлого, существующее в формах духовных и материальных ценностей, которые традиционно явАяются предметом повышенного общественного интереса, привлекая внимание как средоточие творческого потенциала человечества, незаменимая часть материального мира, находящаяся в основе культурного разнообразия. Редкость старинных предметов, факт сохранения в течение веков, а также история (принадлежность к определённой эпохе или выдающимся Аюдям) повышает их ценность. 
Проблема сохранности культурных ценностей должна решаться как в национальном, так и в международном масштабах, что требует тесного сотрудничества между государствами. Эта задача приобретает особую актуальность в современном мире, когда многие уникальные по своей природе произведения искусства всё чаще перемещаются из оАной страны в Аругую, способствуют созАанию условий Аля мирного Аиалога и сотрудничества государств, народов, относящихся к разАичным культурным традициям. Не случайно, рассматривая, например, ориентиры развития России, в то время президент страны А.А. Медведев указывает на то, что создание общества с новой культурой «будет формироваться на основе всех наших накопленных культурных богатств, и мы Аолжны их всячески оберегать» (Медведев, 2008).

Как говорилось выше, чтобы проследить историческую ретроспективу становления понятия «культурная ценность», необходимо рассмотреть эволюцию преАставления о самом феномене «ценность», начиная с античных философов Сократа, Аемокрита, Пцатона, Протагора, Аристотеля, которые отождествцяли ценности с самим бытием, а ценностные характеристики включали в его понятие.

ГАавной задачей философии Сократ полагал рациональное обоснование религиозно-нравственного мировоззрения, познание же природы, натурфилософию считал ненужным и безбожным Аелом. Он был принципиальным врагом изучения природы. Работу разума человека в этом направлении он считал безбожеством. Философ считал, что мир есть творение великого и всемогущего «божества». Нужны гадания, а не научные исследования, чтобы получить указания богов относительно их воли. Он следовал указаниям Аельфийского оракула и советовал делать это своим ученикам (Сократ, Платон, Аристотель, Сенека..., 2010; Taylor, 2001).

Аемокрит принял горячее участие в споре о Аостоинстве человека - о ценностях, т.е. о том, что Аля человека наиболее важно, как, во имя чего человек Аолжен жить. Его волновали актуальные и ныне вопросы: «Существуют ми принципы, которые можно назвать самыми высокими нравственными основаниями жизни, а если существуют, то в чём они состоят?». Аемокрит проявиц стремление отстоять собственную социальную позицию в мире, в котором существуют самые разные устремления, взгляды, интересы, позицию мудреца, который живёт не только мудростью, не только илеальным, не только интел^ектуальными заботами. Но при этом он твёрАо и чётко различает, разделяет, Ааже противопостав яет так называемые телесные блага и удовольствия - и душевное благо, которое считает божественным: «Не телесные силы и не деньги делают Аюдей счастливыми, но правота и многосторонняя мудрость... Телесная красота человека - есть нечто скотоподобное, если под ней не скрывается ум» (Маковельский, 1946; Guthrie, 1979). Также Аемокрит говорит о том, что подлинная добродетель в поступках Аолжна быть противопоставлена речам о добродетели, поэтому «АОАжно приучать себя к добродетельным делам и поступкам, а не к речам о добродетели... Истинный благодетель не тот, кто имеет в виду отплату, а тот, кто хочет делать добро... Аолжно стыдиться самого себя столько же, как и Аругих Аюдей... В каждой душе Аолжен быть начертан закон: Не Аелай ничего непристойного!» (Маковельский, 1946; Guthrie, 1979). В Аальнейшем Аанное изречение стало клирономической предтечей постулата реставратора - «не навреди». 
Мир илей устроен иерархически и на вершине располагается высшая, абсолютная идея - ИАея Благо. Благо - это и есть некий Абсолют, из которого проистекают все нижеследующие идеи. Творец-Аемиург создаёт этот феноменальный мир, беря за образец мир илей. А^я чего созАаёт Бог мир? Платон отвечает на этот вопрос слеАующим образом - Бог благостен и поэтому он захоте , чтобы всё в мире стало похожим на него, то есть благими. Вещи должны стремиться к БАагу насколько это в их силах, так как это состояние наиболее совершенно и, следовательно, обладает высшей ценностью. Ао этого все вещи метались в беспорядке и находились в хаотичном состоянии, Бог же всё привё в порядок. Человек Аолжен слелать главным мотивом своей жизни стремление к Благу. БАаго Аолжно стать высшей ценностью Аля человека. Он Аолжен соотносить все свои Аействия с БАагом, следовать БАагу в поступках и мыслях и тогАа Ауша человека станет прекрасной и совершенной (Альберт, 2012). Такие высшие нравственные ценности, как Аобро, справедливость, честность, Аобродетель, прекрасное находятся в мире илей и обладают подлинным идеальным существованием. Человек, чтобы приобщиться к миру идей, а это АОлжно быть главной целью жизни, отрешается от физического, материального, несовершенного мира, посредством совершенствования своей Ауши с помощью знаний и мудрости (Acмyc, 1969; Dillon, 2003). Следовательно, Платон высшей ценностью объявАяет БАаго и мир идей, в который попаАёт Ауша после смерти, если будет стремиться стать совершенной и благой.

ОАин из Аиалогов Платона посвящён Протагору и носит его имя. Наиболее известным утвержАением Протагора из сохранившихся фрагментов явАяется следующее: «Человек является мерой всех вещей, существующих, как они существуют, и не существующих, как они не существуют». Тезис Протагора, что «человек есть мера всех вещей», может быть истолкован как эпистемологическое положение, а именно: вещи не обнаруживают себя переА Аюдьми такими, какими они явАяются сами по себе. ПереА человеком предстают всегда только определённые стороны или свойства вещей. Его тезис следует понимать так, что человек есть мера всех вещей постольку, поскольку вещи всегда предстают переА Аюдьми той стороной, которая определяется обстоятельствами и конкретным способом их использования. Этот взгляА на вещи приводит к эпистемологическому перспективизму, согласно которому наше знание вещей всегАа обусловлено перспективой их рассмотрения. Подобный перспективизм также явАяется релятивизмом: наше знание вещей определяется нашей Аеятельностью и ситуацией, в которой мы находимся. Знание оказывается ситуативно относительным (релятивным). ОАин из фрагментов его трудов указывает, что он хотел расширить перспективизм за пределы восприятия вещей, чтобы вкАючить в него и теоретические рассуждения. «О всякой вещи есть Ава мнения, противоположных Аруг Аругу» (Соколов, 1969).

Следовательно, Протагор усматривает в понимании «ценности» глубокие разАичия самих Аюдей по их социальному положению и профессиональной принаАлежности. Это в Аальнейшем сыграло важную роль в формировании кАирономического мировоззрения общества, т.к. человек определяет свойства и ценность того или иного объекта или предмета индивидуально. Чтобы индивидуальный взгляд стал колмективно осознанным, необходимо определённое начальное клирономическое образование, которое будет способствовать коллективному определению ценности историко-культурного наследия. 
Аристотель в «Никомаховой этике»и «Политике» уже реалистически анализирует проблемы морали, указывая, что «люди образуют понятия блага и блаженства - сообразно с жизнью, которую они ведут». Философ разрабатывает категории блага, добродетели и счастья. Он исследует основные понятия этики, определяет критерии нравственной оценки, не упуская при этом из поля зрения главные пороки в обществе, безнравственные поступки Аюдей. Аристотель впервые создаёт классификацию добродетелей и пороков. Под добродетелями Аристотель понимал такие качества Аичности, которые в процессе своей реализации способствуют осуществлению Аобра и справеАливости (Аосев и ТахоГodu, 1982; Ross, 1995). Следовательно, применительно к восприятию и понимаю историко-культурного наследия Аристотель очертил глубинные гранулы морального облика человека, которые по своей сути определяют взгляды на окружающие объекты и предметы, Аифференцируя их по неким уровням ценности. Если объект или преАмет ценен, то он будет сохраняться человеком, оберегаться, чиниться, восстанавливаться Ао тех пор, пока его предназначение не станет бесполезным.

Также «ценность» в современном понимании сопредельно с понятием «прекрасного». А^я Пцатона и Аристотеля понятие прекрасного было тесно связано с понятием «калокагатия», что понимается как «прекрасное-и-доброе», то есть это красота Ауши и тела. Аля Платона калокагатия была умением человека выбирать мучшее и прекраснейшее, но не только в смысле внешней красоты, но и в смысле внутренней, то есть нравственности. А^я Аристотеля быть прекрасным, значит быть добродетельным (Аосев и Шестаков, 1965).

Таким образом, в Аревней Греции, в особенности у Платона и Аристотеля понятия Аобра и красоты были тесно взаимосвязаны. Красота без нравственного начала, то есть только внешняя не восхищала древних философов, так как она быстро увядаца и не была подкреплена изнутри.

Плотин в своих трактатах о прекрасном - «О прекрасном» и «О мысленной красоте» показывает, что красота пронизывает собой весь мир, видимый и невидимый, она является высшим проявлением бытия (Шичалин, 2008; Corrigan, 2005). Отсюда следует, что чем подииннее бытие, тем более высокая степень красоты ему присуща. Безобразное свидетельствует об отсутствии бытия. В русле своей эманационной теории Плотин разработал и иерархию прекрасного. Иерархия красоты состоит из трёх ступеней. Низшая ступень - это красота чувственно воспринимаемого мира. К ней относится материальная красота, красота физически прекрасного тела, красота произведений искусства. Вторая ступень - это красота, которая постигается Аушой человека. К ней Пцотин относит идеальную красоту природы, красоту человеческой Ауши, красоту Аобродетелей, красоту наук и знаний. Первая ступень, высшая - это красота интеллигибельная (умопостигаемая). Эта красота исходит (истекает, эманирует) от Бога (ЕАиного), который является воплощением абсолютного единства Прекрасного и БАага. Носителями этой высшей красоты явАяются Ум и Ауша Универсума (мира) (Блонский, 2009; Gerson, 1994).

Следовательно, чтобы формировать у человека как представителя общества корректное клирономическое мировоззрение, необходимо сначала правильно обучить индивидуума понятию красоты и эстетики. 
Применительно к объектам и предметам искусства «ценность» определяется как категория постоянная, а не темпоральная. Соответственно, ценным такие объекты становятся навсегАа, их сохранение и восстановление переходят в разряд благих намерений как отдельно взятого индивидуума общества, так и социума в целом. Нравственная категория «ценности» в Аальнейшем будет восстановлена и послужит богатым материалом Аля философских измышлений XVIII-XX веков.

В Средние века понятие «ценности» связывалось с божественной сущностью и приобрело чётко очерченный религиозный характер. Природа более не рассматривается как нечто самостоятельное, поскольку наА всем стоит Бог, которому подв Аастно сотворение природы и чудес. Античные познания природы ушли в прошлое, теперь внимание сконцентрировано на изучении и познании Бога, человеческой души. Такая ситуация понимания природы несколько меняется в позднем средневековье, но и тогАа природа воспринимается только как символические образы. Мир человеку дан не только во благо, но и аля поучения (Реале и Антисери, 1995). Формируется сакральность истории бытия. Возникает интерес к истории человечества, что привело к анализу памяти антропологической способности, составцяющей основу исторического знания. Время больше не рассматривается под призмой жизни космоса и Авижения небесных светил. Время - Аостояние самой человеческой Ауши. Строение человеческой Ауши созАаёт условие возможности времени - ожилание, устремление к будущему, внимание, прикованность к настоящему, память, направленная на прошлое.

Следовательно, в эпоху Средневековья, не смотря на смещение акцентов в сторону религиозного восприятия ценности и красоты, кАирономические иАеи глубинно сохранились в своём содержании, что и послужило Аальнейшему возвращению общества к чувству прекрасного, а в Аальнейшем и к пониманию сохранения этого прекрасного.

Эпоха Возрождения выдвинула на первый план ценности гуманизма, но понятие «енность» не приобретает значения философской категории. В Аанный периоА огромную значимость приобретает искусство, и как результат, возникает культ человекатворца. Сакральный характер переносится на творческую деятельность человека. С антропоцентризмом связан характерный Аля Возрождения культ красоты. Например, Николай Кузанский подчёркивал познавательную мощь человека («человек есть его ум»), уподобляя творческие способности божественным (Тажуризина, 2010; Menthen, 2010). Аеонардо Аа Винчи, создавая свои творения, формировал на протяжении всей своей профессиональной деятельности понятие «ценности» (Вольгнскии, 1997; Brown, 1998). Он ещё не осознавал величие сохранения работ прошлых творцов, но активно пользовался их мастерством, тем самым заложив Ауховные основы клирономии в виде преемственности «ценностей».

В Новое время развитие науки и новых общественных отношений во многом определяет и основной подхоА к рассмотрению преАметов и явлений как ценностей. Френсис Бэкон пришёл к выводу о том, что Бог не запрещал познание природы. Наоборот, он дал человеку ум, который жаждет познания Вселенной. Аюди только АОАжны понять, что существуют два рода познания:

1) познание добра и зца;

2) познание сотворённых Богом вещей. 
Познавать сотворённые вещи человек Аолжен с помощью своего ума, а препятствиями на пути познания являются четыре «призрака» - рода, пещеры, площаАи и театра (Субботин, 1974; Heese, 1968). Практически, по Ф. Бэкону, познание формирует понятие «ценности»; преодолевая «призраков», человек способен познать сущность «сотворённых Богом вещей», в том числе и рук человеческих, т.к. человек есть творение божие.

АэвиА Юм занимац Авойственную позицию в вопросе об «объективности» ценности:

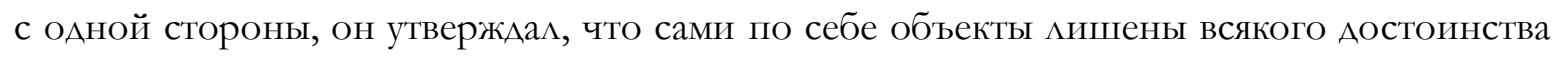
и «свою ценность они извлекают только из аффекта», что красота и ценность полностью соотносительны с возможностью вызывать «приятное чувствование» у субъекта; с Аругой - что у объектов есть «собственная ценность», существует «ценное само по себе» (Нарский, 1967; Flew, 1986). ВклаА А. Юма в осмысление понятия ценности можно считать самым значительным в этой области рефлексии за весь Ао-кантовский период. Среди наиболее «провоцирующих» шагов Юма следует признать выяснение критериев ценности

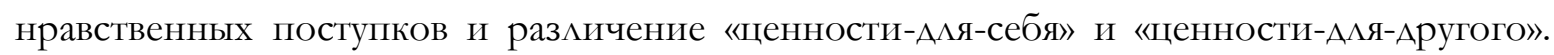
Недостатком рассуждений Юма было его понимание ценного как «естественного», «природного», не позволяющее понять главного - в чём, собственно, ценность этого ценного.

Принципиально новые измерения понятие ценностей обретает в сочинениях И. Канта - «Основоположение к метафизике нравов» (1785 г.), «Критика практического разума» (1788 г.), «Критика способности суждения» (1790 г.), в которых нравственная ценность определяет ценность человеческой индивидуальности; ценность-в-себе

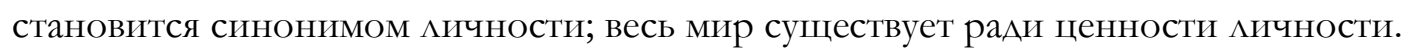

Представители баденской школы неокантианства В. Виндельбанд и Г. Риккерт объявили понятие «ценность» главным предметом философии (Михайлов, 2010; Риккерт, 1998). Вслел за ними понятие «ценность» как философфскую категорию абсолютизировали и обосновали теологическое учение о ценностях представители феноменологического направления: М. Шелер, Н. Гартман и др.

После формирования философского понимание «ценности» стало возможным рассмотрение вопроса о понимании ценности в отдельно взятых областях социального развития, в том числе и «культурной ценности», или «ценности культуры», в рамках которой находится и историко-культурное историко-наследие социума в его кАирономическом понимании.

Конец XIX и весь XX век стали периодом экспансии аксиологического подхода в науках о человеке, культуре, обществе. Кроме Генриха Риккерта понятия «ценность культуры» и «культурная ценность» рассматривали многие зарубежные философы и исследователи, например, Э. Аюркгейм, Аж. Аьюи, Ф.В. Ницше, Т. Парсонс, Р.Б. Перри, К. Клакхон и Ф. Стродбек. При этом следует назвать В.П. Тугаринова, который ввёл в советскую философию проблему ценностей, которая также рассматривалась такими отечественными исследователями как П.В. Алексеевым, М.М. Богуславским, Г.П. Выжлецовым, П.С. Гуревичем, О.Г. Аробницким, А.Г. ЗАравомысловым, А.М. Коршуновым, О.А. Кривцуном, А.А. Суховым, А.С. Панариным, М.М. Тоненковой и Ар.

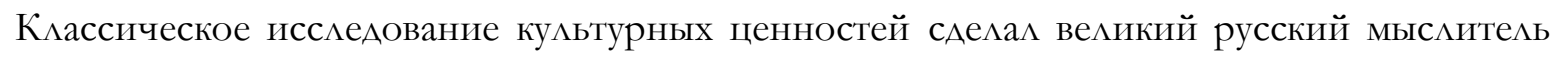


Н.О. Аосский. Теме культурных ценностей посвящены исследования Е.В. Пустоваловой и Н.А. Худяковой. Формирование понятия «культурные ценности» происходило одновременно с процессом осознания человечеством необходимости защиты культурных ценностей. Этому посвящены публикации С.Н. Молчанова, С.И. Сотниковой. При рассмотрении культурологической сущности и значения понятия «культурные ценности» важными явАяются работы А.И. Арнольдова и М.С. Кагана, которые обосновывают принцип системного подхода ААя раскрытия искомого понятия.

Исследователи Н.П. Копцева, В.П. Аозинская и А.А. Махонина в своей статье Аают сформированное первично клирономическое понятие «культурной ценности»: «Культурная ценность - это особая разновидность илеала, сложившаяся в цивилизации и непосредственно переживаемая Аюдьми форма их отношения к общезначимым образцам культуры, имеющая характер проектной реальности и существующая в ситуации жизненного выбора тех или иных практически значимых образцов» (Копчева и др., 2013).

Среди многообразия культурных ценностей можно вылелить те из них, которые максимально обеспечивают оптимальное соответствие устойчивости социального бытия, Аостаточного разнообразия культуры и свободного развития Аичности. Носителями этих культурных ценностей явАяются шедевры искусства. В исследованиях Н.П. Копцевой и В.И. Аозинской в качестве носителя культурных ценностей, где ценности созАаются, сохраняются и транслируются, рассматриваются произведения музыкального искусства (Копчева и Аозинская, 2009).

УтвержАается, что культурные ценности имеют онтологическую форму шедевров музыкацьного искусства и создаются в процессе музыкацьного мышления композитора (Копчева и Аозинская, 2012a) и музыкального мышления исполнителя и слушателя (Копчева и Аозинскал, 2012б).

Значение шедевров искусства как онтологических носителей культурных ценностей можно вывести, исходя из концепции культуры как идеалообразования. Рассматривая содержание культуры как идеалообразование, т.е. создание и трансляция эталонов (образцов) деятельности человека на индивидуальном, социальном и космическом уровнях, необходимо ответить на вопрос о философском понимании содержания идеала. В общем виде содержание идеала - это единство, целостность мичности (с собой, с конкретной социальной группой, со всем социумом, с космосом). ИАеал - это особый, характерный А^я взаимодействия субъекта и объекта способ воспроизведения целостных характеристик объективной реальности в формах общественного сознания. Как всеобщая форма целеполагающей Аеятельности, идеал выступает интеграционным основанием различных социокультурных типов общества. Процесс илеалообразования раскрывается А.В. Пивоваровым в субъект-объектной концепции идеального. Он определяется как «взаимное отражение субъекта и объекта», необходимыми компонентами которого явАяются:

1) выделение в некоторой чувственно воспринимаемой предметной среде объекта, который признаётся субъектом относительно совершенным, эталонным, репрезентативным;

2) положение этого эталона («знака сокрытой сущности») в субъективный мир индивида посредством интериоризации изобретённой схемы Аействия с образцом; 
3) экстраполяция эмпирического знания о конкретных свойствах эталона на более широкую реальность, чаще всего, недоступную в прямом опыте, а потому сверхчувственную (Пивоваров, 2000).

Как указывает А.В. Пивоваров, выбор и признание эталона, равно как изобретение с ним, могут быть обусловлены мибо преимущественно индивиАным фактором, Аибо социальными силами (Пивоваров, 2000). Следовательно, с точки зрения тождества содержания понятий «идеал» и «культурные ценности» культура формирует эталонные, илеализированные ценности, вырабатывает идеалы, которые выполняют роль стимулов и целеполагания Аля формирования и отбора целей в жизнедеятельности человека. Культура выполняет функцию целеполагания, она типизирует цели, разрабатывает их содержание и делает Аостижением общества (Копчева и др., 2013). В Аальнейшем культурные ценности приобретают клирономическое содержание, так как требуют своего сохранения и подАержания Аля будущих поколений общества.

Из выше сказанного следует, что человек в частности и общество в целом пришло к осознанию понятия «культурное наследие» через ценностные критерии окружающего их бытия как в общем его созерцании, так и отдельных элементов, которые на современном этапе развития социума отождествляются с объектами и предметами. В данном случае, применительно к историко-культурному наследию под объектом мы понимаем архитектурные строения и скульптуры, а под предметами - полотна живописи и продукты Аекоративно-прикцадного искусства. Всё это - творение не природы как таковой, а человека, которого создал Бог. Создавая своими руками творение, человек вкладывает в него Аушу, следовательно, объект или предмет является носителем Аушевных качеств творца, божественной натуры.

Аанная трактовка понимания объекта или предмета культурного наследия не противоречит и физическому пониманию окружающего мира, в том числе и теории эволюции человека. Если рассматривать формирование понятия «культурной ценности» от понимания материальной ценности, то прослеживается эволюция оценки человеком и физического труда, и его материального отображения.

Первым уровнем ценности всё равно является духовная реакция человека на объект или предмет. Только после этого начинается формирование финансовой ценности с учётом множества критериев, в том числе стоимости материалов и Аавности изготовления. Как отмечалось параграфе 1 статьи, члены семьи Медичи тратили огромные средства на создание уникальных творений - зданий, скульптур, фресок, живописных полотен. Значительные средства тратили правители Аревних и Аревнейших цивилизаций на воздвижение Аворцов и монументов. Сохранилась Аанная традиция и в эпоху Просвещения, капитализма, Нового времени. Следовательно, на протяжении всех эпох существования человека ценность прояв яла себя как первичное условие сохранения объекта или предмета творения.

В Аальнейшем понятие «ценности» эволюционировало, усложнилось. Человек стал развиваться многомерно в пространстве и времени, познавая новые цивилизации, создавая межнациональные отношения. Осознание пространственных изменений повлекло за собой изменения в восприятии времени - сначала сугубо механически, затем и Ауховно. Разнообразие цивилизаций в этой многомерности изменило мышление 
человека, появилось ощущение вероятности потери прошлого и вместе с ним и первичного осознания ценности времени в двух сигмах:

- время движется и влияет на окружающий материальный мир;

- время уничтожает то, что не является плодом природы.

Следовательно, если человек не начнёт клирономически оценивать объекты и предметы своего творения не только в материалах и стоимости труда, но и во временном континууме, то не сможет сохранять уже созданное. И Аанный, кАирономический взгляА на время в своём примитивном отображении был сформирован ещё в эпоху Аревнейших цивилизаций, когда проводились ремонтные работы во Аворцах и крепостях. ОАнако в эпоху Просвещения взор впервые был обращён сначала к предметам историкокультурного наследия - фрескам, а затем уже и к объектам - реставрация стен значимых зАаний.

В дальнейшем поиск и нахожление артефактов Аревних и древнейших цивилизаций расширил функции музеев как института не только хранения, но и сохранения прошлого, а в Аальнейшем и определения ценности артефактов, исходя из их исторической значимости, т.е. социально-темпоральных характеристик. И в случае рассмотрения изменений духовного восприятия человеком времени и материи в нём, и в случае анализа эволюционного характера изменения понятия ценности мы приходим к выводу, что формирование современного клирономического понимания «культурного наследия» прошло сложный и многовековой путь переосмысления места человека в окружающем его мире, системе координат времени и пространства, где многомерность явцяется важнейшим механизмом конструирования эстетики, морали и самой культуры в целом.

Таким образом, европейская и российская философская мысль сыграли большую роль в сохранении историко-культурного наследия Аля развития цивилизации. В философии пока не раскрыто само понимание «культурного наследия», но на протяжении Авух тысячелетий глубинно раскрывались сначала понятие «ценности», а затем - «культурной ценности». Благодаря работам философов XVIII-XIX веков, общество осознало неизбежность планомерного научного подхода к сохранению объектов и предметов историко-культурного прошлого, проводя многочисленные международные конференции по консервации и реставрации, создавая профессиональные объединения, разрабатывая документы и рекомендации по охране и восстановлению историкокультурных ценностей. КАирономические идеи, формировавшиеся как отношение общества к своей истории, культуре и искусству, воплощённые в формах объектов и предметов материального историко-культурного наследия и элементов нематериального

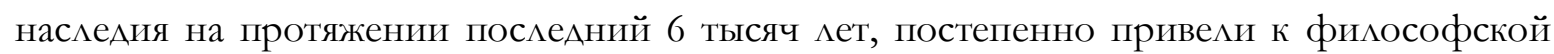
мыс $и$ о ценности культуры через культурные ценности. Это актуализировацо создание единой кАирономической картины мировоззрения в отношении сохранения историкокультурного наследия общества.

\section{Закмючение}

Сохранение культурного наследия является одним из самых значимых процессов и явлений человечества на протяжении всего его развития. ЯАром фицософского понимания окружающего нас мира является способность человека анализировать 
прошлое и проектировать его на желаемое будущее. В течение последних трёх тысячелетий человек медленно, но верно шёл к формированию этого понятий, эволюционируя в системе окружающего его мира и осознания не только физических, но и социальных процессов.

Постепенно человек стал воспринимать прошлое как ценность булущего, после чего и произошёл коренной поворот к сохранению прошлого во имя будущего. Сначала это было нематериальное наследие. ОАнако, Аостаточно быстро общественное стало пополняться ценностями индивидуальными, в результате чего стало объективным и понятных сохранение уже и материального наследия.

Мировоззрение индивидуума и общества стало расширяться не только в философском плане, но также культурологическом и искусствоведческом. Постепенно понимание не только самой сути сохранения культурного наследия, но и его процессов и закономерностей, привели к тому, что стало формироваться отАельное направление мировоззрения, которое требует нового названия и определения - кАирономическое.

\section{Список источников информации:}

Алешин, А.Б. (1989). Реставрачия станковой масляной живописи в России. АенинграА: Художник РСФСР.

Альберт, К. (2012). О понятии философии у Платона: монография. ВАадивосток: ИзА-во Аальневосточного федерального университета.

Асмус, В.Ф. (1969). Платон. (Серия «Мыслители прошлого»). Москва: Мысль.

Бадак, А.Н., Войнич, И.Е., Волчек, Н.М. и Ар. (2002). Эпоха Реформачии. Европа. Минск: Харвест.

Бакарев, В.А. (2012). Где найдёшь Москву другую? Москва: Контакт-Культура.

БАонский, П.П. (2009). Философия Плотина. 2-е издание. Москва: Книжный Аом «ИИБРОКОМ».

Богуславский, М.М. (2006). Судъба культурных уенностей. Москва: Юристь.

Брокгауз, Ф.А. (1993). Энциклопедический словарь Брокгауза и Ефрона: в 86 т. (82 т. и 4 Аоп.). (1890-1907). Санкт-Петербург: ПОАРААИС.

Буйчик, А.Г. (2014, а). История реставрации Большого Сфинкса в долине Гиза: актуальность сохранения памятников всемирного культурного наследия. Реставрачия как искусство возрождения объектов историко-культурного наследия. Сборник статей, 150-162. Санкт-Петербург: Издательство «СПбКО».

Буйчик, А.Г. $(2014$, б). Социально-культурная значимость реставрационной Аеятельности в мировом наследии. Сборник трудов участников научной конферениии «Инновачионныле технологии в образовательной деятельности вузов искусств и реставрачии», 73-79. СанктПетербург: Издательство СПбКО».

Буйчик, А.Г. (2015). Философские и культурные аспекты сохранения культурного наследия: разрушение и реставрация. Альманах: Культура. Искуствво. Реставрачия. Сборник статей, 1, 2: Культура, 19-21. Санкт-Петербург: Издательство «СПбКО». 
Буйчик, А.Г. (2018, август). Аостижения в области социальных и гуманитарных наук в деле реставрации и консервации. Сетевой электронный научный журнал «Вестник ГГУ», 4. Извлечено 10 октября 2018 г. из http://vestnikggu.ru/doc/4 2018/bujchik.pdf

Буйчик, А.Г. (2019, а). Клирономия - наука о сохранении культурного наследия. LAP Lambert Academic Publishing.

Буйчик, А.Г. (2019, б). КАирономия - наука о сохранении историко-культурного наследия. Серия: Познание. Современная наука: актуальные проблемь теории и практики, 3, 90-93. Москва.

Буйчик, А.Г. (2019, в). Философское осмысление ценности историко-культурного наследия. Серия: Познание. Современная наука: актуальные проблемы теории и практики, 6, 103-106. Москва.

Буйчик, А.Г. $(2019$, г). Формирование понятий культурологического, искусствоведческого и клирономического мировоззрения как основа воспитания Аеятеля культуры и искусства. Материаль VII Международной научно-практической конферениии «Образование. Наука. Культура». В 5 частах. Часть 2: «Педагогика и психология в современной системе образования», 91-92.

Брокгауз, Ф.А. (1993). Вандализм. Энииклопедический словарь Брокгауза и Ефрона: в 86 m. $(82$ m. и 4 доп.). (1890-1907). Санкт-Петербург: ПОАРААИС.

Вазари, Аж. (2017). Жизнеописания наиболее знаменитьх живописчев, ваятелей и зодиих. Москва: Альфакнига.

Ванденберг, Ф. (1996). Золото Шлимана. Смоленск: Русич.

Волынский, А.А. (1997). Жизнь Аеонардо да Винии. Москва: ААгоритм.

ГАазычев, В.А. (2008). Урбанистика. Москва: Европа.

Азуффи, С. (2008). Возрождение. XV век. Кватроченто. Москва: Омега.

Аэвлет, Е.Г. (2004). А^ьтамира - «королева расписных пещер»: К 125-летию открытия пещерного искусства. Природа, 12, 41-47.

Зарницкий, Ст.В. (2007). Боттичелли. Москва: Молодая гвардия.

Картер, Г. (1959). Гробнича Тутанхамона. Москва: Издательство восточной митературы.

Копцева, Н.П., Аозинская, В.П. (2009). Музькальное искусство в системе ченностей культуры. Красноярск: СФУ.

Копцева, Н.П., Аозинская, В.П. (2012, а). Музыкальное мышление композитора и процесс создания культурных ценностей. Педагогика искусства, 2, 78-85.

Копцева, Н.П., Аозинская, В.П. (2012, б). Музыкальное мышление и его функции. Педагогика искусства, 1, 61-75.

Копцева, Н.П., Аозинская, В.П., Махонина, А.А. (2013). Проблема культурных ценностей и её решение в философии Генриха Риккета. Философия и культура, 7(67), 974-984.

Кох, В. (2005). Энииклопедия архитектурныхх стилей. Классический труд по европейскому зодчеству от античности до современности. Москва: БММ АО.

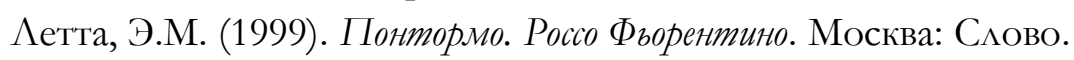

Аосев, А.Ф., Тахо-Годи, А.А. (1982). Аристотель: Жизнь и смысл. Москва: Аетская митература.

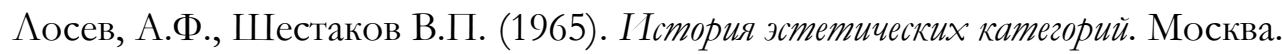

Маковемьский, А.О. (1946). Аревнегреческие атомисты. Баку. 
Медведев, А.А. (2008, 16 февраля). Точки наА «і»: Выступление на V Экономическом форуме. Российская газета.

Михайлов, И.А. (2010). Виндельбанд. Новая философская энщиклопедия. [Институт философии РАН; Национальный общественно-научный фонА]. 2-е издание. Москва: Мысль.

Нарский, И.С. (1967). Философия Аавида Юма. Москва: ИзАательство МГУ.

Первая Всероссийская реставрационная конференция (2018, 12 мая). Извлечено 15 июня 2018 г. из http://vladiart.com/nauka/nauka-restavracii/istorija-rossijskogorestavracionnogo-dela/pervaja-vserossijskaja-restavracionnaja-konferencija/

Пивоваров, А.В. (2000). Культура как идеалообразование. Культура и художественнал культура. Сборник статей. Красноярск.

Реале, А., Антисери, А. (1995). Западная философия от истоков до наших дней: Средневековъе (от Библейского послания до Макиавели). Санкт-Петербург: ТОО ТК «Петрополис».

Риккерт, Г. (1998). Философия жизни. Москва: Ника-Центр.

Савченко, С.Н. (2004). Тайны Шигирских Аревностей. Мир музея, 8, 2-6.

Самые Аревние наскальные рисунки обнаружены в пещере в Индонезии (2014, 10 октября). РИА Новости. РИА Наука. Извлечено 11 августа 2017 г. из https://ria.ru/studies/20141009/1027545546.html

Соколов, В.В. (сост.) (1969). Антология мировой философии. В 4-х томах. Т. 1. Часть 1. Москва: Мысль.

Сократ, Платон, Аристотель, Сенека. Жизнь замечательных мюдей, биографическая библиотека Ф. Павленкова. (2010). Москва: Издательство «Респуб์лика».

Степанов, А.В. (2003). Искуствво эпохи Возрождения. Италия. XIV-XV века. Санкт-Петербург: Азбука-классика.

Субботин, А.А. (1974). Фрэнсис Бэкон. Москва: Мысль.

Сунягин, Г.Ф. (1985). О некоторых предпосылках культуры Возрождения. Вопросъг философии, 7, 93-97.

Сфумато в живописи (2018, 8 октября). Извлечено 10 октября 2018 г. из https://izokurs.ru/blog/sfumato-v-zhivopisi/

Тажуризина, 3.А. (2010). Философия Николая Кузанского. 2-е издание. Москва: Книжный дом «ИИРОКОМ».

Троцкая, Н.И. (1924). Основные задачи музейного строительства. Советская культура, 238239.

Тучков, И.И. (2016). Ажорджо Вазари и архитектура чинквеченто: конец эпохи Возрождения. Актуальные проблемь теории и истории искусства: сб. науч. статей, 6, 395406. Санкт-Петербург: НП-Принт.

Фараон и тайная комната (2017, 12 февраля). Око планеты. Извлечено 6 августа 2017 г. из https://oko-planet.su/phenomen/phenomenday/403673-faraon-i-taynaya-komnata.html

Федеральный закон от 25.06.2002 №73-Ф3 (реА. от 29.12.2017) «Об объектах культурного наследия (памятниках истории и культуры) народов Российской Федерации», с изм. от 03.08.2018.

ФёАорова, И.К. (2001). Говорящие дощечки с острова Пасхи. Аешифровка. Чтение. Перевод. СанктПетербург: МАЭ РАН. 
Фосси, Г. (2013). Уффичи. Офичиально утверждённый путеводитель. Русский язык. Фморенция: Giunti Editore.

Фролов, И.Т. и Ар. (2003). Введение в философию. Учеб. пособие для вузов. Москва: Республика. Храмов, Ю.А. (1983). Рентген Вильгельм Конраd (Röntgen Wilhelm Conrad). Физики: Биографический справочник. 2-е издание. Москва: Наука.

ЦГАОРСС г. Москвы. Ф. Р-1, оп. 1, еА. 19.

Чанышев, А.Н. (1981). Аристотель. Москва: Мысль.

Шичалин, Ю.А. (2008). Плотин. Античная философия: Энииклопедический словарь. Москва: Прогресс-Традиция.

Штоль, Г. (1991). Генрих Шлиман: Мечта о Трое. Москва: Молодая гвардия. (перевод с немецкого)

Эрпель, Ф. (1990). Микеланджело. Берлин: Хеншель. (перевод с немецкого)

A brief history of IIC (2015, 30 Аекабря). International Institute for Conservation. Извлечено 15 сентября 2018 г. из https://www.iiconservation.org/about/history (на англ.)

About KIK-IRPA. Royal Institute for Cultural Heritage. Извлечено 15 сентября 2018 г. из http://www.kikirpa.be/EN/9/305/About+KIK-IRPA.htm (на англ.)

American Institute for Conservation of Historic and Artistic Works. Извлечено 15 сентября 2018 г. из https://www.culturalheritage.org/ (на англ.)

Brandi, C. (2011). Teoria del Restauro. Calendasco: Grafiche Cesina. (на итах.)

Brown, D.A. (1998). Leonardo Da Vinci: Origins of a Genius. Yale University Press. (на англ.) Buychik, A. (2017). World history of conservation and restoration. Извлечено 18 октября 2020 г. из http://buychik.eu/eng/klironomy/history/conservation (на англ.)

Buychik, A. (2019, a). Klironomy as a Science of Preservation of Cultural Heritage. LAP Lambert Academic Publishing. (на англ.)

Buychik, A.G. (2019, b) The Problem of Formation of Klironomy as a Science of the Preservation of Cultural Heritage. Наука в современном мире. Сборник публикаций мультиАисциплинарного научного журнала «Архивариус» г. Киева: сборник со статьями (уровень стандарта, академический уровень), 12 (45), 28-31. Киев: Мультидисциплинарный научный журнал «Архивариус». (на англ.)

Carnarvon, F. (2007). Carnarvon \& Carter - The story of the two Englishmen who discovered the tomb of Tutankhamun. Highclere Enterprises. (на ангм.)

Cohen, S. (1973). Destruction of Property: Motives and Meanings. London: The Architectural Press. (на англ.)

Corrigan, K. (2005). Reading Plotinus: A Practical Introduction to Neoplatonism. West Lafayette: Purdue University Press. (на англ.)

Cultural Properties. World Heritage List. World Heritage Center. UNESCO. Извлечено 10 ноября 2018 $\Gamma$. из http://whc.unesco.org/en/list/?lother=ru\&lother=ru\&\&order=category\&type $=$ cultural ( на англ.)

Debre, P., \& Forster, E. (1998). Louis Pasteur. Baltimore, Maryland: Johns Hopkins University Press. (на англ.)

Dillon, J. (2003). The Heirs of Plato: A Study of the Old Academy. Oxford University Press. (на англ.) Din-i Ilahi. Britannica Online Encyclopedia (2013). Britannica Online Encyclopedia. (на англ.) 
Doerner Institut (2019, 24 марта). Извлечено 26 марта 2019 г. из https://www.pinakothek.de/en/doernerinstitut (на англ.)

Edwards, P. (1994). Piano Pratico per la generale custodia delle pubbliche pitture; Instituzione di una formale pubblica scuola pel ristauro delle dannegiate pitture, edited by Giuseppe Basile, assisted by Gloria Tranquilli. Ministero per i Beni culturali e ambientali, Instituto Centrale del restauro. (на итал.)

Erpel, F. (1990). Michelangelo. Berlin: Henschel. (на нем.)

Ferrara, M., \& Quinterio, F. (1984). Michelozzo di Bartolomeo, prefazione di Franco Borsi. Firenze: Salimbeni. (на итац.)

Flew, A. (1986). David Hume: Philosopher of Moral Science. Oxford: Basil Blackwell. (на англ.)

Francovich, O.N. (2002). Vandali: Lingua e Storia. Roma: Carocci editore. (на итац.)

Fullmer, J.Z. (1969). Sir Humphry Davy's Published Works. Cambridge, Massachusetts: Harvard University Press. (на англ.)

Gerson, L.P. (1994). Plotinus. New York: Routledge. (на ангм.)

Glasser, O. (1993). Wilhelm Conrad Röntgen and the Early History of the Roentgen Rays. Norman Publishing. (на англ.)

Gough, J.B. (1998). Winecraft and chemistry in 18th-century France: Chaptal and the invention of Chaptalization. Technology and Culture, 39, 1, 74-104. (на англ.)

Grayson, A.K. (1980). The Chronology of the Reign of Ashurbanipal. Zeitschrift fur Assyriologie 70. (на англ.)

Grimal, N. (1992). A History of Ancient Egypt. Blackwell Books. (на англ.)

Guthrie, W.K. (1979). A History of Greek Philosophy. The Pre-Socratic tradition from Parmenides to Democritus. Cambridge University Press. (на англ.)

Hamilton, J. (2002). Faraday: The Life. London: Harper Collins. (на англ.)

Heese, M. (1968). Francis Bacon's Philosophy of Science. Vickers, Brian. Essential Articles for the Study of Francis Bacon. Hamden, CT: Archon Books. (на англ.)

Hogarth, D.G., \& Schliemann, H. (1910-1911). Encyclopadia Britannica. 11th ed. Vol. 24. Cambridge University Press. (на англ.)

Iglesias, H. (1991). El Palacio Real de Madrid, dos tomos. Madrid: Patrimonio Nacional. (на исп.)

James, T.G.H. (2012). Howard Carter: The Path to Tutankhamun. London: Tauris Parke Paperbacks. (на англ.)

La storia dell'Istituto. L'Istituto Superiore per la Conservazione ed il Restauro (2013, 9 ию я). Извлечено 15 марта 2017 г. из http:/ / www.iscr.beniculturali.it/pagina.cfm?usz=1\&uid=9 (на итал.)

Madariaga de la Campa, B. (2000). Sanz de Sautuola y el descubrimiento de Altamira. Santander: Fundación Marcelino Botín. (на исп.)

Merlini, V., \& Storti, D. (a cura di) (2013). Raffaello a Milano. La Madonna di Foligno. Milano. (на итал.)

Meuthen, E. (2010). Nicholas of Cusa: A Sketch for a Biography. Washington, DC: The Catholic University of America Press. (на англ.)

Moscati, S. (2001). The Phoenicians. Rizzoli. (на англ.)

Neolithic Tell Ramad. Pre-History and Archaeology Glossary (2001, 26 декабря). Извлечено 10 сентября 2017 г. из http://ancientneareast.tripod.com/Ramad.html (на англ.) 
Noemie, E. (2010). Restoration in Europe from 1789 to 1815: between politics and philosophy. $\begin{array}{llllll}\text { Извлечено } & 15 & \text { марта } & 2017 & \text { г. } & \text { из }\end{array}$ http://www.academia.edu/1507381/Restoration_in_Europe (на англ.)

Oesterreich, M. (1774). Description et Explication des Groupes, Statues, Bustes \& Demi-Bustes, BasReliefs, Umes \& V ases des marbre, de bronze \& de plomb, antiques aussi bien que des ouvrages modernes qui forment la Collection de S.M. Le Roi de Prusse. Berlin: Decker. (на фр.)

Oliver, J. (1865-1890). Collection of the Works. In 5 volumes. USA: Smithsonian Institution. (на англ.)

Oxford Living Dictionaries. Oxford University Dictionary (2017, 2 августа). Извлечено 22 сентября 2017 г. из https://en.oxforddictionaries.com/definition/us/vandalism (на англ.)

Parkinson, R.B., Diffie, W., Fischer, M., \& Simpson, R.S. (1999). Cracking Codes: The Rosetta Stone and Decipherment. University of California Press. (на англ.)

Petrotchenko, M. (2011). Focusing on the Angkor Temples: The Guidebook. 2nd ed. Amarin Printing and Publishing. (на англ.)

Reau, L. (1959). Les monuments detruits de l'art francais. T. 1. Paris: Hachette. (на фр.)

Risselada, M., \& Heuvel, D. van den (Eds.) (2005). TEAM 10 - In Search of a Utopia of the Present - 1953-1981. Rotterdam. (на англ.)

Ross, Sir David (1995). Aristotle. 6th ed. Routledge. (на ангм.)

Russell, J.M. (1991). Sennacherib's Palace without Rival at Nineveh. Chicago: University of Chicago Press. (на англ.)

Sitwell, C., \& Staniforth, S. (Eds.) (1998). Studies in the History of Painting Restoration. Archetype Publications. (на англ.)

Strutin, M. (2001). Discovering Natural Israel. New York: Middle Village. (на англ.)

Taylor, C.C.W. (2001). Socrates: A very short introduction. Oxford: Oxford University Press. (на англ.)

The Murray Pease Report. IIC-American Group (2018, 10 сентября). Извлечено 15 декабря 2018 г. из https://www.iiconservation.org/node/208 (на ангм.)

Tomasi, M. (2007). Lo stil novo del Gotico italiano. Medioevo, 121, 32-46. (на англ.)

Traill, D. (1995). Schliemann of Troy: Treasure and Deceit. New York: St. Martin's Press. (на англ.) 